\title{
Hybrid renewable mini-grids on non-interconnected small islands: Review of case studies
}

\author{
A.A. Eras-Almeida , M.A. Egido-Aguilera
}

A B S T R A C T

Keywords:

Hybrid renewable mini-grids

Non-interconnected

Small islands

Renewable energy

Access to electricity

Business models

\begin{abstract}
Most small islands, with populations of between 1000 and 100,000 inhabitants, have non-interconnected power generation systems consisting of thermal power plants. This affects their ecological balance and implies a financial dependency on the price of fossil fuels and high electricity generation costs. However, small islands can accelerate their energy transition to become lower-carbon economies thanks to their enormous renewable energy potential. This research presents the current state of the art of hybrid renewable mini-grids (HRMGs) on noninterconnected small islands. To do so, a comparative analysis was applied among islands located in the Atlantic and Arctic, Pacific and Indian Oceans, and the Caribbean and Mediterranean Seas based on an extensive review of the literature. This study identifies business models applied to support the introduction of renewable energy and the key factors for the implementation of HRMGs on small islands. This review highlights how developed islands are successful in achieving their ambitious renewable energy targets. On the other hand, it is demonstrated that the least developed islands from the Pacific and Indian Oceans need to strengthen their weak regulatory frameworks and define suitable business models to promote renewable energy projects, involving private entities. Furthermore, these islands should find alternative funding sources apart from foreign aid. Developing islands should guide international cooperation in favor of effective policies and fostering local capacities. In those regions, thanks to the low prices of renewable technologies, the most attractive mechanisms for the implementation of HRMGs are the Renewable Energy Service Company model, competitive auctions and tax incentives.
\end{abstract}

\section{Introduction}

Although energy was not mentioned in the Millennium Development Goals (MDGs) [1,2], the 2030 Agenda for Sustainable Development recognizes the crucial role of energy in development processes. It also underlines how access to modern and sustainable energy is essential to eradicating poverty, saving lives, improving health conditions and satisfying basic human needs [3]. This Agenda highlights the need to transform the way energy is produced and consumed to eliminate poverty and foster sustainable development. Moreover, it also calls for a paradigm shift towards green economies, particularly in developing countries and emerging markets [4].

To accelerate the transition process to modern energy systems, Sustainable Energy for All (SE4ALL) identifies a series of High Impact Opportunities (HIOs) whose goal is to achieve synergies between actors, sectors and industries in order to progress towards access to universal

Abbreviations: ADB, Asian Development Bank; BVIEC, British Virgin Islands Electricity Corporation; CREBs, clean renewable energy bonds; DGs, diesel generators;

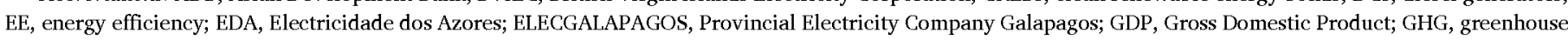

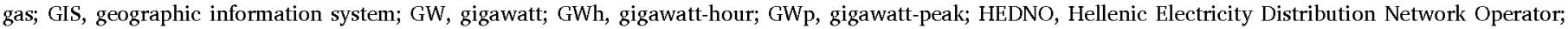

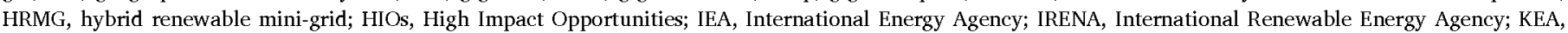

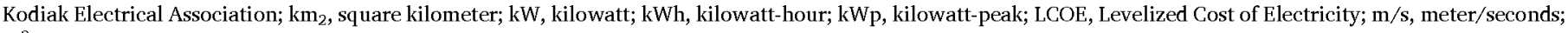

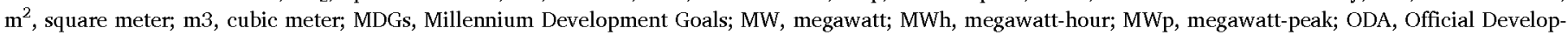

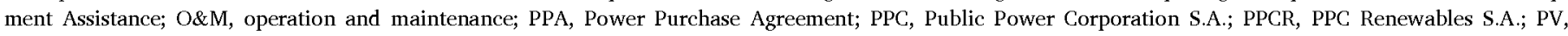

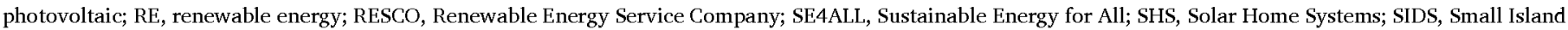
Developing States; USD, dollar of United States; USc, cents of dollar. 
energy. ${ }^{1}$ These HIOs link renewable mini-grids to sustainable power sources and consider them a tool to be included in government and international plans. HIOs allow the definition of different business models, promoting knowledge, making them visible and facilitating access to both public and private funding. ${ }^{2}$ The energy transition involves society, institutions, innovative financing mechanisms, the promotion of private investment, ownership structures and the global economy $[5,6]$.

\subsection{The market for renewable mini-grids}

Mini-grids based on renewable energy (RE) sources are a viable alternative for rural areas, islands, and developed and developing island states to increase their access to energy. Consequently, it is possible to decrease the use of diesel, to cut down the costs and improve the quality of the electricity service, and to combat the consequences of climate change [7-10]. Renewable mini-grids encompass the economic and social benefits in rural areas and for local business, such as the increase in the agricultural production, the creation of new jobs, increased incomes and achievements in health and education [9,11]. Furthermore, these systems offer opportunities for diversification and competitiveness to electric generation companies [10].

During the past decade, across the world, the number of mini-grids has grown steadily. For instance, in 2017, photovoltaic (PV) solar energy and small hydro mini-grids have reached 308 and $509 \mathrm{MW}$ of capacity, respectively [12,13]. In 2016, 9 million people were connected to mini-grids with RE [13]. The potential for the mini-grid sector is huge. There are currently still 1.06 billion people with no access to electricity (14\% of the global population) [14]. The scenarios predicted by the International Energy Agency (IEA) show that between 2017 and 2030: 485 million people will gain access to electricity through decentralized power systems (mini-grids will connect $60 \%$ of this population), while the energy needs of 185 million people will be covered by the power grid. The implementation of mini-grids requires an investment of $\$ 188$ billion US [14].

Even though single technology mini-grids could achieve the big objectives in access to energy, Wiemann et al. [15] concluded that the most cost-effective option to provide electricity is the hybrid renewable mini-grid (HRMG). In fact, a study based on seven countries proved that hybridization could reduce the average cost of generation by $0.3 \%-8 \%$ under market conditions. Even if the public sector funds the projects, this reduction could be from $12 \%$ to $16 \%$ [16]. The diesel capacity worldwide that could be hybridized with renewables varies from 50 to $250 \mathrm{GW}$ [7], of which $15 \mathrm{GW}$ is on small islands (definition based on the number of inhabitants from 1000 to 100,000 ) [17]. It is estimated that $70 \%$ of households in the Pacific islands have no access to electricity [18], and the wind and solar potential to hybridize diesel generation is 4.97 MW and 2.95 MW respectively [17]. A number of variables have to be analyzed to develop HRMGs, such as the socio-economic situation, the geography, the environment and the regulatory framework of the respective islands. These aspects, added to the natural island context, influence the success or failure of business models [19].

\subsection{Hybrid renewable mini-grids: an opportunity on islands}

"Healthy, well-managed and diverse ecosystems and resources can play a strong role in mitigating future environmental challenges and improving livelihoods everywhere" [20]. The vulnerability of islands to global climate change makes it imperative to take immediate action to reduce greenhouse gas (GHG) emissions related to the use of fossil fuels [21]. Most islands worldwide have off-grid generation systems made up of thermal power plants, thus affecting the cost of electricity and the reliability and safety of the power supply $[8,22]$. However, their energy transition can be accelerated thanks to their abundant RE resources [22, 23]. The common objective of these territories is to achieve energy independence using RE [24], the first step towards sustainable development [25].

There are 87,000 islands [26] that cover approximately $7 \%$ of the Earth's surface [27]. The island population worldwide stands at 740 million people [26] and around 3\% (20 million inhabitants) live on 1785 small islands whose population is between 1000 and 100,000 [17]. At least half of this group of small islands is in the Pacific Ocean (half of the total island population). It is estimated that the high potential of solar and wind energy could hybridize the $15 \mathrm{GW}$ of installed thermal capacity (diesel) on small islands. ${ }^{3}$ That means $7.5 \mathrm{GWp}$ of solar energy and $14 \mathrm{GW}$ of wind energy combined with $5.82 \mathrm{GWh}$ of battery capacity could reduce per year 7.8 billion liters of diesel consumption and 20 million tons of GHG atmospheric emissions [17].

Small islands and Small Island Developing States (SIDS) could save up to $\$ 10$ billion US/year in fuel costs; an average of 3.3\% of their Gross Domestic Product (GDP). Although this number may seem low, the truth is that many poor islands mainly from the Pacific and the Indian Ocean spend up to $20 \%$, and even $30 \%$ of their GDP on fuel [17,28]. In SIDS, $90 \%$ of their electricity is produced using imported oil [29-31]. Thus, an increase of $\$ 10$ US/barrel would result in a reduction of $1.5 \%$ of their GDP [29]. This vulnerability to the fluctuation in oil prices affects the cost of transport, communications and electricity which in turn gives rise to a side-effect on poverty rates and real income $[22,30,32]$. The Pacific SIDS are the most vulnerable to this external influence [33] due to disadvantages such as the limitation in achieving economies of scale, insularity, remoteness, the limited availability of land, dispersed population, high susceptibility to natural disasters, the dependency on foreign countries and environmental vulnerability [31,34,35].

HRMG is the best option for small islands to increase RE penetration in the electricity mix, especially where there is no interconnection with the mainland [36]. Even though the contribution of small islands and SIDS to the global reduction in GHG emissions is low [17], these islands can show the rest of the world how fossil fuel independence is not just a conceptual idea for the future. ${ }^{4}$ Some islands from developed countries generate $100 \%$ of their electricity by renewable resources [22], with diesel generators (DGs) working as a back-up, e.g., El Hierro, Graciosa and Kodiak $[7,37]$. To accelerate energy transition, the constraints of each island and economic incentives must also be considered in the planning phase $[38,39]$. In some cases, the constraints may be institutional, social and financial issues $[35,40]$ or in others, environmental and technical $[25,36]$. Establishing robust energy policies is a priority to link the local and national goals with the 2030 Agenda and international commitments to set out an appropriate and reliable regulatory framework $[41,42]$.

The following questions arise therefore in this research:

- Which business models are used to implement HRMGs on noninterconnected small islands?

- What are the key technical, political, economic, financial and environmental factors to take into account in developing HRMGs on noninterconnected small islands?

- The adoption of which policies to facilitate the implementation of HRMGs arise in this review?

The research presented here describes the state of the art of electricity generation with RE based on mini-grids on non-interconnected 
small islands. This review includes a comparative analysis between islands located in the Pacific, Atlantic and Arctic (considering both regions as a single region), and Indian Oceans, the Caribbean and Mediterranean Seas. This paper attempts to show why the configuration of renewable systems varies from one island to another, the difficulties and challenges of their implementation and how different business models can support the deployment of HRMGs. To this end, this research identifies: (i) the business models implemented to hybridize thermal power plants on non-interconnected small islands, using the definition of business models based on rural electrification experiences as a reference [15,19,43-45]; and, (ii) the main technical, social, political, financial and environmental factors related to RE penetration. The findings are helpful to promoters, decision-makers, researchers and other stakeholders involved in the development of RE projects.

\section{Methodology}

A previous study shows that there are 1785 small islands worldwide whose population is between 1000 and 100,000 [17]. Through a geographic information system (GIS), this study has established these islands are distributed as follows: 890 islands are in the Pacific Ocean, 380 in the Atlantic and Arctic Oceans, 319 in the Indian Ocean, 103 in the Caribbean Sea and 93 in the Mediterranean Sea [17]. The total electricity consumption of these small islands is around 50, $000 \mathrm{GWh} /$ year which involves a high demand for fossil fuels $[17,46]$. These areas are not usually interconnected with the mainland, even with nearby islands because of the high costs of submarine cable connections. This makes the provision of electricity less stable and reliable [22]. To overcome these disadvantages, small islands, which are considered as mini-grids for the purpose of this paper, can hybridize their current diesel power systems through the use of the enormous potential of REs, especially from solar and wind power [46].

The same study reveals, through a technical and economic assessment, that there are differences between the islands depending on the location. For example, Mediterranean islands, which belong to developed countries, are characterized by the highest GDP/capita while the islands in the Indian Ocean have the lowest. The Pacific islands have the highest Levelized Cost of Electricity (LCOE): $45 \mathrm{USc} / \mathrm{kWh}$, due to their remoteness and transport costs. In the Atlantic and the Pacific Oceans, there is the highest potential for wind $(6.44 \mathrm{GW})$ and PV (2.95 GWp) projects respectively. On small islands, the estimated potential hybridization is between $10 \%$ and $97 \%$ [17].

Based on this information, this study analyzes at least one island per region (the Pacific, Atlantic and Arctic and Indian Ocean, Caribbean and Mediterranean Seas) to define the main factors that support the development of HRMGs. To reach this goal and to provide reliable answers to the aforementioned research questions: first, a classification matrix has been designed to compile descriptive information on the islands. This information involves their geographical location, vulnerability factors, available renewable resources, economic activity, public policies aimed at promoting $\mathrm{RE}$, business models and financial mechanisms used to hybridize thermal systems and the identification of implemented renewable technology and storage systems. Furthermore, the matrix includes a number of data considered of interest in this research: area $\left(\mathrm{km}^{2}\right.$ ), population, GDP (million USD), GDP per capita (USD/year), total installed capacity (MW), percentage of RE used in the power generation mix (\%), electricity consumption (MWh/year and $\mathrm{kWh} /$ capita/year) and peak demand (MW). These indicators strengthen the characterization in this work.

Second, 10 case studies detailed in Table 1 have been selected from four basic criteria: (i) at least one island per region, (ii) the population is between 1000 and 100,000, (iii) the islands have non-interconnected power systems with the mainland, and (iv) the islands have hybridized their mini-grids with RE. The islands have been selected from the list of small islands provided by the Reiner Lemoine Institut ${ }^{5}$ (as stated in Ref. [17]), with the exception of Necker Island which is a unique example of a private island with only 60 inhabitants.

This research has been developed by analyzing scientific literature to build a proper state of the art of electricity generation with RE-based hybrid mini-grids on non-interconnected small islands. Furthermore, it was necessary to gather information and data from complementary documents, such as government reports, web sites, official statistics and company surveys. Through a descriptive and comparative analysis, a number of examples are cited to better illustrate the situation of the islands in this study.

\section{Key definitions}

\subsection{Mini-grids}

Mini-grids rely on one energy source and connect multiple clients [54]. There are two types which involve high electricity prices in comparison with hybrid mini-grids: (i) 100\% renewable energy power systems that usually need batteries to store surplus electricity in order to guarantee the reliability of the electricity service. The installed capacity of these renewable systems tends to be higher than the capacity of diesel or hybrid systems to produce enough electricity to be stored. This increases the electricity prices compared with hybrid systems and reduces the lifetime of the batteries due to their constant and higher use; and, (ii) $100 \%$ fuel power systems which are dispatchable but have environmental impacts. Investment in diesel gensets is lower than that of renewable power systems. However, the annual running costs are more expensive because of the high levels of operation and maintenance (O\&M) of diesel gensets and the cost of fuel [15].

\subsection{Hybrid renewable mini-grids}

HRMGs are characterized by the use of different sources of energy generation (any combination of PV, wind and hydro energy, diesel and storage systems) and because these systems have one or more clients [54]. The use of HRMGs is currently widespread to foster the exploitation of renewable resources. These systems ensure the reliability, quality and security of the electricity service [55], and provide socioeconomic and environmental benefits $[55,56]$. These systems are highly recommended for off-grid locations such as small islands [55,57]. DGs usually integrate these systems as a back-up [8] or to overcome the need for batteries [54]. Regarding efficiency and economics, storage systems are a challenge for islands [57].

Both mini-grids and HRMGs require control systems for frequency and voltage stability to enable an economical and optimum operation [36,58-60]. Both systems could operate as grid-connected or island-mode [58]. In the context of islands, both mini-grids and HRMGs could connect to the mainland. This paper considers an HRMG as a centralized system capable of supplying the most power demand of a non-interconnected small island.

\subsection{Business models for the implementation of hybrid renewable mini- grids}

Political and regulatory conditions play a fundamental role in offgrid business development and their adaptability to local circumstances $[15,61]$. This is especially relevant in HRMGs and the difficulty in setting them up. These frameworks could become either opportunities or barriers in ensuring their operation [15]. Robust governance is a pre-requisite to meeting the needs of consumers, owners and suppliers, and in reducing the risk to stakeholders [61]. The pillars for ensuring the 
Table 1

\begin{tabular}{|c|c|c|c|c|c|c|c|}
\hline Country & Name & Island or archipelago & Location (ocean or sea) & $\begin{array}{l}\text { Area } \\
\left(\mathbf{k m}^{2}\right)\end{array}$ & $\begin{array}{l}\text { Elevation } \\
\text { (msnm) }\end{array}$ & Population & Source \\
\hline Spain & El Hierro & Canary Islands & Atlantic & 274.6 & 1501 & 14,849 & [47] \\
\hline Portugal & Graciosa & Azores Archipelago & Atlantic & 60.8 & 408 & 4966 & [47] \\
\hline SIDS Associate Member & Tokelau & 3 atolls (i) & Pacific & 12 & & 1411 & {$[48]^{a}$} \\
\hline SIDS & Tuvalu & 4 coral reefs and 5 atolls (ii) & Pacific & 26 & & $\begin{array}{l}10,782 \\
(2014)\end{array}$ & $\begin{array}{l}{[23,} \\
49]\end{array}$ \\
\hline Ecuador & Galapagos & $\begin{array}{l}19 \text { major islands and } 200 \text { islets } \\
\text { (iii) }\end{array}$ & Pacific & 8.01 & 864 & $\begin{array}{l}29,658 \\
(2015)\end{array}$ & [50] \\
\hline United States & Kodiak & Kodiak Archipelago (iv) & Pacific & 9433.1 & 1353 & 13,950 & [47] \\
\hline $\begin{array}{l}\text { United Kingdom, SIDS Associate } \\
\text { Member }\end{array}$ & Necker & British Virgin Islands & Caribbean & 0.18 & & 60 & [51] \\
\hline Greece & Ikaria & Island & Mediterranean & 258.4 & 1037 & 6869 & [47] \\
\hline Australia & King Island & Island & $\begin{array}{l}\text { Indian (Bass Strait - } \\
\text { Tasmania) }\end{array}$ & 1109.8 & 213 & 1938 & [47] \\
\hline SIDS & Seychelles & 115 islands (v) & Indian & 455 & 905 & $\begin{array}{l}93,400 \\
(2015)\end{array}$ & $\begin{array}{l}{[52,} \\
53]\end{array}$ \\
\hline
\end{tabular}

(i) Fakaofo, Atafu, Nukunonu.

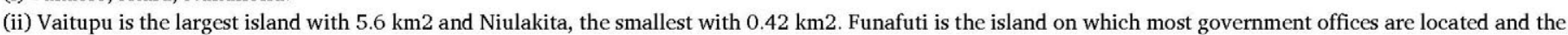
center for sea and air transport.

(iii) 5 inhabited islands: San Cristobal, Santa Cruz, Baltra, Isabela and Floreana.

(iv) Kodiak is the largest island in the archipelago.

(v) $95 \%$ of the population lives in Mahé (main island), Praslin and La Digue.

${ }^{a}$ Both Tokelau and Necker are SIDS Associate Members. Available at: http://www.unesco.org/new/en/natural-sciences/priority-areas/sids/resources/sids-list/.

long term sustainability of funding, installation, and O\&M of HRMGs are business models. Ownership is a decisive factor in classifying business models $[15,43,62]$. Nevertheless, these models must be adapted to the necessities and circumstances of every location [15]. In this research, the owner will be defined as the entity responsible for setting up and financing the project. These entities could be international organizations and donors [63] but it has to be clear that the ownership does not determine responsibility for the O\&M [15]. Donor aid has traditionally led seed-financing in developing countries [43]. According to the literature that describes experiences for implementing mini-grids in rural areas, the most common organizational models are:

\subsubsection{Public model}

It is the most common model in developing countries. The main advantage of this model is the access to financing, subsidies and to the technical staff in the public sector [43]. The main disadvantages of this model are the lack of interest in O\&M and projects linked to political agendas that change according to the interests of the government in office $[15,43]$.

\subsubsection{Private sector model}

The private sector financing carries out the project. It is in charge of the O\&M of the systems and, unlike public companies, it can react better to political ramifications [43]. Private companies require public incentives, such as grants or loan guarantees $[15,19,43,44]$ but this does not mean that the public sector funds projects.

\subsubsection{Community-based organization model}

It is a very common model in which the contribution of both the private and the public sector is limited [15]. The community sets up cooperatives and owns the system. It is responsible for its administration, O\&M and the collection of payments $[15,19,43,44]$. This model fosters employment in O\&M-related activities. It also guarantees the quality of the service, because the users are the owners [15]. However, the community-based organization model usually suffers from social conflicts and the lack of technical skills $[15,61]$. This model also needs the assistance of the public and private sectors [15].

\subsubsection{Hybrid model}

This model is a combination of the aforementioned models to minimize their deficiencies and complexities so that every participant assumes a specific role in the investment, implementation or management of the systems $[15,19,43,44]$. The contractual agreements of this model may be:

- Public-private partnerships: It establishes a relationship between the public and the private sector to develop projects or provide services through shared commitments [64], for instance, the public sector can finance, own and manage the hybrid mini-grid while the private sector can be responsible for the O\&M [44].

- Concessions: The private sector is responsible for an exclusive geographic area to provide electricity for a certain period of time. This model often becomes a monopoly and is usually supported by subsidies $[44,65]$.

- Power Purchase Agreement (PPA): It is a contractual agreement to deliver electricity where generation and distribution assets are owned and controlled by different parties [44]. PPA is expected to include O\&M activities as revenues depend on the performance of the system [59].

- Renewable Energy Service Company (RESCO): It provides services through activities such as the implementation of RE projects, especially in emerging markets $[66,67]$. The RESCO takes on a degree of risk. This model uses the revenue stream that comes from cost savings or RE produced to make the project profitable [68]. There are two ways of establishing a contract: (i) Shared savings: the RESCO finances the project and the client pays a part of savings obtained to the RESCO; (ii) Guaranteed savings: the client is the investor and the RESCO guarantees the annual energy savings to cover the debt incurred by the client [66-68].

To identify business models implemented on islands, it is necessary to adjust the previous definition and classify the business models according to the aforementioned definition of ownership. To guarantee a sustainable operation of HRMGs it is common to transfer the ownership rights, responsibilities and risks to local entities. However, when donors or international agencies are the investors [43], it is important to differentiate foreign aid participation from other sources of funding depending on the location of the islands. This becomes more relevant if the new vision of RE deployment wants the public sector to fund the pre-investment phase of projects where private equity is a complement $[31,45]$. 


\section{Characterization of case studies: drivers and inhibitors of renewable energy}

Fernandes and Pinho [69] observed that the most common constraints of small islands are the scarcity of natural resources, environmental fragility and small domestic markets. However, these islands differ in size, the degree of remoteness, available RE resources, economic specialization and the level of economic wellbeing. This section analyzes the factors that drive or inhibit the implementation of HRMGs.

\subsection{Size, remoteness and insularity}

Small islands have a series of disadvantages due to their sizes such as their dependence on the external market and their limited natural resources. These disadvantages imply a large dependency on foreign exchange earnings and the elevated import content of their GDP $[34,70]$. Their small markets and their limited ability to achieve economies of scale and to replace imported products affect internal prices and limit endogenous development $[34,69]$. The infrastructures of some of these islands are barely developed and their financial, human and natural resources are limited [70]. Because of their remoteness and their insularity, ${ }^{6}$ transport costs are high and the provision of supplies is not guaranteed [34]. This also affects the price of electricity mainly on the Pacific islands. There, for the next 20 years, the estimated average cost of thermal generation is the highest at the regional level at 45.1 $\mathrm{USc} / \mathrm{kWh}^{7}$ [17]. In this sense, the most vulnerable islands in the study are Tuvalu and Tokelau, which are some of the most remote countries in the world [70,71]. In 2002, in Tokelau, the electricity generation costs were about \$1.02 US/kWh in Fakaofo, \$1.30 US/kWh in Nukunonu and $\$ 1.82 \mathrm{US} / \mathrm{kWh}$ in Atafu. The electricity tariff was subsidized, then the prices in the respective atolls were 50,35 and $30 \mathrm{USc} / \mathrm{kWh}$ respectively [72]. Fuel comes from Samoa (another Pacific Island Country) and is stored in Fakaofo. Cargo ships distribute it from there to every atoll [48, 72]. Similarly, in the Galapagos Islands, there are subsidies for thermal generation, and its price reaches $12.32 \mathrm{USc} / \mathrm{kWh}$ [73]. The costs of shipping the diesel to Baltra ${ }^{8}$ are $49 \mathrm{USc} /$ liter and the final customer pays 51 USc/liter. This final price takes into account the weighted fuel cost $^{9}$ and the expenses derived from transport, storage, commercialization and applicable taxes $[74,75]$. For the residential sector in the Galapagos Islands and the mainland, the electricity tariff is the same on average: $9.8 \mathrm{USc} / \mathrm{kWh}$ for an electricity consumption of between 0 and $500 \mathrm{kWh}$ [76]. Both Tokelau and the Galapagos Islands have protectionist governments who subsidize both fuel imports and the final consumer tariff. The remoteness, the small size and the geographical fragmentation of the Pacific islands restrict their economic development [40]. Integrating RE systems as a driver in the energy transition of every small island is necessary for them to become low-carbon energy systems [77] and more resilient to their natural conditions.

\subsection{Environmental factors}

Human presence and population growth are a constant danger to the ecosystems of small islands $[34,70]$. This demands an increasing amount of local and imported resources and service provision. Furthermore, these islands are susceptible to natural disasters that impact their economies directly and disrupt the delivery of services $[34,69]$.

\footnotetext{
${ }^{6}$ Every island is defined as insular but not all of them are located in remote areas [34].

7 Thermal generation prices have been calculated on the basis of the 2014 costs (\$0.74 US/liter) plus an annual rise of $3 \%$ [17].

${ }^{8}$ Baltra Island is the distribution center for diesel to the other islands (Santa Cruz, San Cristobal, Isabela and Floreana islands).

${ }^{9}$ Weighted cost results from the weighting the price of the imported product and that of the price of the domestic product [76].
}

\subsubsection{Ecological vulnerability}

The exploitation of natural resources to deploy agricultural and livestock productivity, housing and the development of tourism can compromise islands' ecosystems. Therefore, finding a balance between economic, environmental and social requirements is important in maintaining the ecological sustainability of small islands [69]. Several islands have been awarded different designations due to the preservation of their natural reserves (both land and marine) and their biodiversity to foster sustainable economic growth. Some well-known examples are $\mathrm{El} \mathrm{Hierro} \mathrm{and} \mathrm{Graciosa}[78,79]$ named as "Biosphere Reserves", and the Galapagos Islands designated a "World Heritage Site". On the island of El Hierro, $58 \%$ of the land surface is protected [80]. In the Galapagos Islands, $3 \%$ of the surface of the islands is inhabited and the Galapagos National Park encompasses the other $97 \%[81,82] .{ }^{10}$ In terms of energy, the scarcity of ground due to the presence of protected areas is another factor to be considered in energy planning in line with climate impacts [83]. For instance, solar power plants need an extensive area of land for their installation. However, protected areas make it more difficult to obtain environmental licenses from local utilities, make decisions about the location of power plants or their refurbishment [83]. The definition of a suitable location for new power systems should avoid affecting the biodiversity of these contexts.

\subsubsection{Climate and susceptibility to natural disasters}

Small tropical islands are often hit by cyclones and other extreme weather events, whose effects are huge in human, environmental and financial terms [70]. Islands are usually located in areas susceptible to natural disasters with geological and hydrological origins $[34,70]$. For instance, Kodiak, the largest island in the Kodiak Archipelago, is located in the Pacific Ring of Fire [84]. Two tsunamis hit the island and destroyed the settlement of Old Harbor in 1788 and 1964. In 1964, the tsunami, which was brought about by a megathrust earthquake ${ }^{11}$ [85], wiped out the public and private facilities that required a replacement at a cost of \$22 million US [86]. In 1912, the volcanic eruption of Mount Novarupta ${ }^{12}$ covered the island in ashes and devastated the local fishing industry [84]. In the case of SIDS, the damage caused by natural disasters per surface unit and the costs per capita are bigger than on the mainland [34], for instance, in the Seychelles, the total cost of damage from earthquakes and storms was $\$ 39$ million US from 2004 to 2013 . ${ }^{13}$ From an energy security perspective, energy systems have to provide an ongoing electricity service, avoiding aggravating a hazard during a natural disaster. This means that the introduction of RE technologies and a reliable infrastructure help to configure a resilient and sustainable energy system [87]. As an example, after the nuclear catastrophe in Japan in 2011, private and public sectors are implementing mini-grids and HRMGs to overcome the downturn in nuclear power [88] supported by Japan's subsequent energy plan [89].

\subsection{Renewable energy potential}

REs have been playing a crucial role in sustainable development especially in areas with problems of electricity shortage [90,91] such as on islands. Expanding access to energy and replacing fossil fuels to

\footnotetext{
${ }^{10} \mathrm{http}: / /$ areasprotegidas.ambiente.gob.ec/es/todas-areas-protegidas-por-re gion? $\mathrm{t}=\mathrm{G}$.

11 "The Mw 9.21964 Alaska earthquake ruptured $a>100,000 \mathrm{~km}^{2}$ area from east of Valdez to Kodiak Island" [86]

12 Mount Novarupta is 100 miles off Kodiak [85].

${ }^{13}$ Data about natural disasters on islands is available at: https://www.emdat. be/.
} 
decarbonize the power sector and mitigate climate change are the objectives of the introduction of RE [92,93]. The techno-economic RE capacity ${ }^{14}$ on small islands is $14 \mathrm{GW}$ of wind power and $7.5 \mathrm{GWp}$ of solar power. However, the high cost of transactions and the ignorance of its potential have slowed down the penetration of RE [17].

In the Atlantic and Arctic islands, the wind power potential is $6.44 \mathrm{GW}$ and that of solar power is $1.94 \mathrm{GWp}$ [17]. The island of El Hierro is one of the best locations with high wind speeds that can reach from 8 to $10 \mathrm{~m} / \mathrm{s}$ [94]. In addition, in the Canary Islands, in the upper reaches of the mountainous islands, the daily irradiation is $7 \mathrm{kWh} / \mathrm{m}^{2}$, and in the north, the irradiation is less than $6 \mathrm{kWh} / \mathrm{m}^{2}$ [83]. The solar potential is considerable for installing PV technology.

In the Pacific, the wind and solar potential is $4.97 \mathrm{GW}$ and $2.95 \mathrm{GWP}$ respectively, and the storage capacity is $2.27 \mathrm{GWh}$ [17], e.g., in Tuvalu, the average radiation is $5.5 \mathrm{kWh} / \mathrm{m}^{2} /$ day; the maximum wind speed is $5.79 \mathrm{~m} / \mathrm{s}$ at a height of $30 \mathrm{~m}$ on Funafuti, which would allow the installation of small turbines of between 20 and $50 \mathrm{~kW} .{ }^{15}$ Their potential to produce biomass and biofuel is also great, because of the number of coconut trees that grow on the islands (1600 ha) [49]. In Tokelau, using its solar resource, coconut biofuel and a good storage system, enough electricity to cover $150 \%$ of the electricity demand can be produced [95]. Nevertheless, in Tuvalu and Tokelau, biomass production is conditioned by high labor and transportation costs $[48,49]$. The Galapagos Islands are one of the most suitable areas to install solar thermal and PV technologies in Ecuador [96]. There is no information on biomass resources but biofuel generation is the most costly RE alternative because jatropha is cultivated on the mainland (i.e. jatropha production cost: $66.94 \mathrm{USc} / \mathrm{kWh}$, biofuel generation cost: $24.50 \mathrm{USc} / \mathrm{kWh}$ ) [73]. ${ }^{16}$

In the other regions such as the Mediterranean islands, a capacity of $894 \mathrm{MW}$ and 972 MWp of wind and solar power respectively can be installed [17]. As an example, in the Aegean region, where Ikaria is located, the mean wind speeds range from between 7 and $9 \mathrm{~m} / \mathrm{s}$ [97]. The solar potential is more than $5 \mathrm{kWh} / \mathrm{m}^{2} /$ day especially during the summer, supporting the excessive electricity requirements of the tourism sector during this period of the year. Furthermore, on some islands, there are geothermal and biomass resources [98]. The Caribbean islands can introduce $1.25 \mathrm{GW}$ of wind capacity and $905 \mathrm{MWp}$ of solar capacity [17]. In the small Caribbean islands in the east, wind speeds are between 8 and $9 \mathrm{~m} / \mathrm{s}$ in the dry season (May to November) and between 6 and $7 \mathrm{~m} / \mathrm{s}$ in the wet season (December to April) [99]. Finally, RE potential in the Indian Ocean Islands is: $319 \mathrm{MW}$ of wind power and $704 \mathrm{MWp}$ of solar power [17]. In the Seychelles, a technical study established the usable RE potential until 2030: 16 MW of wind power, up to $40 \mathrm{MWp}$ of solar power, $5 \mathrm{MW}$ of biomass power, $2 \mathrm{MW}$ of hydropower and $7 \mathrm{MW}$ of waste-to-energy [100].

As regards sources of fresh water, this is lacking on most islands in the world, but there is a lot of seawater that can be used as pumped energy and water supply [101]. This means that only those islands with a high and medium elevation can install hydro and pumped storage power plants [102]. These include El Hierro and the Seychelles (sea water), and Kodiak and Ikaria (freshwater) and the Galapagos Islands (sea and freshwater). On the other hand, the flat and very small islands of Tuvalu and Tokelau have no hydro potential [103]. These islands,

\footnotetext{
${ }^{14}$ The Reiner Lemoine Institut developed an optimization tool to obtain the techno-economic renewable energy potential of 1785 small islands. This tool needs parameters as input: economic data, feed-in time series of renewable energies and load data to optimize the power generation of the islands through the substitution of fossil power generation by RE [17]

${ }^{15}$ In Tuvalu, there is no crane to install larger turbines. However, turbines of $250 \mathrm{~kW}$ with tilt-up towers could be another cost effective solution because these turbines do not require cranes to be installed [49].

16 https://www.iica.int/es/prensa/noticias/premio-are-award-2017-para -el-proyecto-piñón-de-manabí-para-galápagos.
}

which are not suitable for installing ground intensive energy systems, have the opportunity to install roof systems [102]. Biomass is the least cost-effective RE solution because production and transportation costs are high, especially on scattered islands and archipelagos such as the Pacific islands.

The availability of renewable resources is decisive for the integration of new technologies. Although this integration process has been quite slow [70], the efforts made to introduce RE (explained in section 7) in the generation mix deserves recognition, especially when the size, geography and protected natural areas of small islands limit the integration of RE.

\subsection{Economy}

There is a strong compelling between GDP and energy consumption [102,104,105]. An increase of $1 \%$ in capital increases the elasticity of GDP by $0.85 \%$ related to energy consumption [105]. Thus, economic activities are a fundamental factor in calculating the renewable systems on islands properly [102]. Table 2 details the economic data of the islands analyzed.

According to Blechinger et al. [17], the Mediterranean islands have the highest GDP per capita, $\$ 31,400$ US/year, followed by the Arctic and Atlantic, Caribbean, Pacific and Indian islands. Neves et al. [57] identified that higher electricity demand per capita characterizes islands which belong to developed countries and have tourist activity. However, there are some islands that do not completely follow these patterns. For instance, in contrast to the rest of the Pacific islands ( $\$ 15,900$ US of GDP/cap), Kodiak is one of the islands with a high GDP (\$31,900 US) and electricity consumption per capita $(6976 \mathrm{kWh})$. This island is home to the largest Coast Guard Base in the United States and the third most productive fishing port in the country $[84,106]$. The seafood industry impact on Alaska's economy was $\$ 262$ million US for the period between 2015 and 2016 [107]. In the Seychelles, one of the countries with the highest income in Africa, the services sector represents $81 \%$ of GDP (including tourism) [53] which consumes 55\% of the electricity supplied (324 GWh/year) [92]. This archipelago has an electricity demand (3472 kWh per capita/year) very similar to the Island of El Hierro (3233 kWh per capita/year) which has a power desalination power plant. The Galapagos Islands have one of the fastest growing economies in the world (10\% in the period 2005-2009), thanks to the tourist sector [81]. The current growth rate of this sector is unsustainable as it demands an increase in public services and other resources [50,81]. In 2014 alone, the number of tourists was 215,691 , almost seven times the population of the island that year [50]. ${ }^{17}$ This reveals the same fact that other authors concluded in Refs. [108,109]: small islands with attractive tourism have a high rate of economic growth together with a high level of electricity consumption.

Lastly, the most vulnerable economy is Tuvalu. This archipelago, which ranks third in the poverty index among the developing countries of the Pacific members of the Asian Development Bank (ADB), has a trust fund that contributes more than $10 \%$ of the government budget [49]. One feature shared by SIDS is their high external financial dependency, mostly on migrant remittances and Official Development Assistance ODA [31,34]. In terms of financing, market and governance, Tuvalu has made less progress than other Pacific SIDS [103]. From 1997 to 2017, Tuvalu received $\$ 373$ million US from donors, and the ODA per capita was $\$ 2368$ US in 2017 , twice as much as in $1997 .{ }^{18}$ The big differences between developing islands and those of the Atlantic and Mediterranean are brought about by the degree of dependency on external aid and by the limited local economic resources that can be allocated to support

\footnotetext{
17 http://www.ecuadorencifras.gob.ec/proyecciones-poblacionales/.

18 The information about international aid received by Tuvalu is available at https://data.worldbank.org/indicator/DT.ODA.ODAT.CD. and https://data. worldbank.org/indicator/DT.ODA.ODAT.PC.ZS.
} 
Table 2

\begin{tabular}{|c|c|c|c|c|c|c|c|}
\hline Country & $\begin{array}{l}\text { Location (ocean or } \\
\text { sea) }\end{array}$ & Name & & $\begin{array}{l}\text { Island GDP } \\
\text { (million USD) }\end{array}$ & $\begin{array}{l}\text { GDP per } \\
\text { capita (USD) }\end{array}$ & Economic Activity & Source \\
\hline Spain & Atlantic & El Hierro & & 371 & 24,985 & Tourism & {$[47,110]$} \\
\hline Portugal & Atlantic & Graciosa & & 96 & 19,331 & $\begin{array}{l}\text { Agriculture, silviculture, fishing and a } \\
\text { developing tourism sector }\end{array}$ & {$[47,79]$} \\
\hline SIDS Associate Member & Pacific & Tokelau & & 10 & 7087 & Public administration and commerce & $\underset{b}{[23,48,95]}$ \\
\hline SIDS & Pacific & Tuvalu & & 40 & 3710 & Public administration and commerce & $\begin{array}{l}{[23,49,} \\
111]\end{array}$ \\
\hline \multirow[t]{3}{*}{ Ecuador } & \multirow[t]{3}{*}{ Pacific } & \multirow[t]{3}{*}{ Galapagos } & Santa Cruz & 122 & 7993 & \multirow[t]{3}{*}{ Fishing, tourism and science } & \multirow[t]{3}{*}[47,50]{} \\
\hline & & & San & 66 & 8702 & & \\
\hline & & & $\begin{array}{l}\text { Cristobal } \\
\text { Isabela }\end{array}$ & 32 & 13,843 & & \\
\hline United States & Pacific & Kodiak & & 445 & 31,900 & Fishing and services & {$[47,84]$} \\
\hline $\begin{array}{l}\text { United Kingdom, SIDS } \\
\text { Associate Member }\end{array}$ & Caribbean & Necker & & $\mathrm{N} / \mathrm{A}^{\mathrm{a}}$ & $\mathrm{N} / \mathrm{A}$ & Tourism and financial services & [112] \\
\hline Greece & Mediterranean & Ikaria & & 239 & 34,794 & $\begin{array}{l}\text { Tourism, agriculture, farming and services } \\
\text { (transport, health, education) }\end{array}$ & {$[47,113]$} \\
\hline Australia & Indian Ocean & King Island & & 10 & 5160 & $\begin{array}{l}\text { Agriculture, silviculture, fishing and a } \\
\text { developing tourism sector }\end{array}$ & $\begin{array}{l}{[23,47,} \\
114,115]\end{array}$ \\
\hline \multirow[t]{3}{*}{ SIDS } & \multirow[t]{3}{*}{ Indian Ocean } & \multirow[t]{3}{*}{ Seychelles } & Mahé & 484 & 6223 & \multirow{3}{*}{$\begin{array}{l}\text { Services (tourism included) industry and } \\
\text { agriculture }\end{array}$} & \multirow[t]{3}{*}[47]{$^{c}$} \\
\hline & & & Praslin & 71 & 9346 & & \\
\hline & & & La Digue & 14 & 5451 & & \\
\hline
\end{tabular}

\footnotetext{
${ }^{\text {a }}$ N/A Information is not available.

b http://www.tokelau.org.nz/Bulletin/April+2017/GDP+first.html.

c http://thecommonwealth.org/our-member-countries/seychelles.
}

their development.

\section{Policies to promote renewable energy}

The dependency on fossil fuel, the volatility of fuel prices and the adverse effects of climate change are interests common to the islands studied. Table 3 shows the ambitious goals that these islands have adopted to switch from conventional energy models to sustainable ones. Island territories need to guarantee the energy supply to their population in a safe, affordable and reliable manner. These islands have the possibility to do it thanks to their high RE potential and the use of new technologies. Some authors agree $[40,103]$ that RE deployment has to be supported by energy efficiency (EE) measures. EE should consider synergies between a wide range of sectors such as power, heating, transport and cooling $[116,117]$. The current strategies of energy planning involve the link between $\mathrm{RE}$ and $\mathrm{EE}[38,110,116,118]$.

Nevertheless, only those islands belonging to developed countries are achieving their goals. As in other contexts [125], the least developed islands did not consider their socio-economic conditions and geographical features in drawing up reliable and realistic policies. Fig. 1 shows the relationship between RE share and electricity demand per capita, which demonstrates a great heterogeneity between case studies. Since 2008, the goals of European islands have been: (i) to increase the penetration of RE, (ii) reduce GHG emissions and, (iii) improve EE through bottom-up strategies as summarized in the "Package on Climate Change 20-20-20" [38]. There are two more initiatives to strengthen the package: "Clean Energy for EU Islands" and "Smart Islands Initiative" [116]. In this region, the islands of El Hierro and Graciosa, which have already achieved a $100 \%$ of RE penetration, are the most efficient of the group of developed islands in terms of electricity consumption. On the other hand, since 2011, in SIDS, the International Renewable Energy Agency (IRENA) has been supporting the RE transition through the "SIDS Lighthouses Initiative" [117]. SIDS have not been able to achieve their own targets due to lack of funding as well as the tendency of islanders to increase their electricity consumption [40,49]. Only Tokelau has achieved $70 \%$ of RE share due to its very low electricity consumption. However, the New Zealand government could not fund a biofuel power plant to complement the PV system [40]. Tuvalu has a really high electricity consumption compared with the case studies and its level of development is the lowest of the group ( $\$ 3710$ US/cap). This makes it hard to achieve a high RE share. Weir [40] concluded the main RE barriers of the Pacific Islands are social, institutional and financial. There, EE policies should be more intensive to create a collective awareness of the efficient use of energy, and RE policies should change radically to take local conditions into account.

Furthermore, energy policies also aim to preserve the natural land and sea areas by preventing oil spills in these islands. For instance, Kodiak (1989) and Galapagos (2001) were affected by oil spills, where 41.6 million and 681.3 thousand liters of fossil fuel were spilled respectively. The oil spread around the islands and polluted their marine reserves and their beaches $[84,126]$. In addition, in Tuvalu, Galapagos and Seychelles, the access rate to electricity is $99 \%,{ }^{19} 99.83 \%$ and $98 \%$ (one of the highest rates in the Indian Ocean SIDS) respectively [92,127, 128]. In SIDS, there seems to be constant competitiveness between access to electricity and RE targets. The government provides subsidies to clients connected to the grid but not for rural electrification [18]. According to the 2030 Agenda, allowing access to electricity to a greater number of people is compulsory. Indeed, access to electricity is a right and an implicit attribute of other rights such as non-discrimination or sustainable development. Some nations have included access to electricity as a right within their national policies $[129,130]$. In this case, where centralized HRMGs (defined in section 3.2.) is unable to cover the demand of the most dispersed people, innovative Solar Home Systems (SHS) would allow the islands to increase their levels of access to electricity.

The Pacific and Seychelles need to reform their governance to overcome unrealistic targets, the limited capacities and private investment, together with the inherent barriers of their nature $[18,103]$. In contrast, the rest of the islands studied have more rigid energy policies to achieve high shares of RE. There, stable institutions are developing robust energy programs with private support in most cases.

\section{The identification of business models}

The source of funding is the main pillar for classifying business models in this research. There is a wide range of partnerships between the different levels of public companies, between public and private

\footnotetext{
19 https://islands.irena,org/RE-Progress/Country-Profiles.
} 
Table 3

Islands' policies.

\begin{tabular}{|c|c|c|c|}
\hline Name & Policy/Initiative & Goal & Source \\
\hline El Hierro & $\begin{array}{l}\text { The White Book and the EU } \\
\text { Action Plan } \\
\text { Island Management Plan of } \\
\text { El Hierro }\end{array}$ & $\begin{array}{l}\text { To ensure energy supply } \\
\text { with renewable sources } \\
\text { To reach } 100 \% \text { of } \\
\text { renewable energy } \\
\text { generation }\end{array}$ & $\begin{array}{l}\text { [78, } \\
119]\end{array}$ \\
\hline Graciosa & & $\begin{array}{l}\text { To reach } 100 \% \text { renewable } \\
\text { energy use }\end{array}$ & [120] \\
\hline \multirow[t]{3}{*}{ Tokelau } & $\begin{array}{l}\text { Tokelau National Energy } \\
\text { Policy and Strategic Action } \\
\text { Plan (NEPSAP) } 2004\end{array}$ & $\begin{array}{l}\text { To exploit the natural } \\
\text { resources of the islands to } \\
\text { reduce fuel imports for } \\
\text { power generation }\end{array}$ & $\begin{array}{l}{[48,} \\
121]\end{array}$ \\
\hline & $\begin{array}{l}\text { Tokelau National Strategic } \\
\text { Plan } 2010 \text { to } 2015\end{array}$ & $\begin{array}{l}\text { To improve energy } \\
\text { efficiency and to integrate } \\
\text { renewable energy into the } \\
\text { energy mix. }\end{array}$ & \\
\hline & $\begin{array}{l}\text { Tokelau Renewable Energy } \\
\text { Project (TREP) }\end{array}$ & $\begin{array}{l}\text { To reach } 100 \% \text { of } \\
\text { renewable energy } \\
\text { generation }\end{array}$ & \\
\hline Tuvalu & $\begin{array}{l}\text { Tuvalu National Energy } \\
\text { Policy (TNEP) (2009) } \\
\text { Master Plan for Renewable } \\
\text { Electricity and Energy } \\
\text { Efficiency in Tuvalu } \\
2012-2021 \text { "Enetise } \\
\text { Tutumau" }\end{array}$ & $\begin{array}{l}\text { To generate } 100 \% \\
\text { renewable electricity by } \\
2020 \text {. To increase energy } \\
\text { efficiency on Funafuti by } \\
30 \%\end{array}$ & [49] \\
\hline Galapagos & $\begin{array}{l}\text { Galapagos Islands Zero } \\
\text { Fossil Fuel Initiative }\end{array}$ & $\begin{array}{l}\text { To reach } 100 \% \text { of } \\
\text { renewable energy } \\
\text { generation (without a } \\
\text { specific year to achieve it) }\end{array}$ & [122] \\
\hline Kodiak & $\begin{array}{l}\text { Alaska aims for } 50 \% \text { of } \\
\text { renewable energy } \\
\text { generation by } 2025\end{array}$ & $\begin{array}{l}\text { Through the Pillar } \\
\text { Mountain Project: to } \\
\text { produce } 95 \% \text { of its energy } \\
\text { from renewable sources } \\
\text { and to reduce the } \\
\text { dependence on diesel and } \\
\text { the electricity production } \\
\text { costs }\end{array}$ & [106] \\
\hline Necker & $\begin{array}{l}\text { Initiative of Richard } \\
\text { Branson (island owner) }\end{array}$ & $\begin{array}{l}\text { To reach } 100 \% \text { of } \\
\text { renewable energy } \\
\text { generation }\end{array}$ & [123] \\
\hline Ikaria & $\begin{array}{l}\text { National policy to reach } \\
20 \% \text { of renewable } \\
\text { generation by } 2020 \text { and } \\
40 \% \text { by } 2040\end{array}$ & & [113] \\
\hline $\begin{array}{l}\text { King } \\
\text { Island }\end{array}$ & $\begin{array}{l}\text { Australia seeks to reach } \\
20 \% \text { of renewable } \\
\text { generation by } 2020 \text {. The } \\
\text { state of Tasmania seeks to } \\
\text { reach } 100 \% \text { renewable } \\
\text { share by } 2022 \\
\text { King Island Renewable } \\
\text { Energy Integration Project } \\
\text { (KIREIP) }\end{array}$ & $\begin{array}{l}\text { Reduce the dependence on } \\
\text { diesel, provide reliable and } \\
\text { quality electricity supply } \\
\text { and the Community } \\
\text { Service Obligation subsidy } \\
\text { in the longer term }\end{array}$ & $\begin{array}{l}{[51} \\
124]\end{array}$ \\
\hline Seychelles & $\begin{array}{l}\text { The energy matrix will be } \\
\text { diversified in the long term. }\end{array}$ & $\begin{array}{l}\text { To reach } 100 \% \text { renewable } \\
\text { energy: } 5 \% \text { by } 2020 \text { and } \\
\text { the other } 15 \% \text { by } 2030\end{array}$ & $\begin{array}{l}{[23,} \\
53]\end{array}$ \\
\hline
\end{tabular}

companies and between them and cooperation agencies, as well as the many possible ways of distributing tasks. Five models have been identified in this research: public, public - private partnership, public private - community-based partnership, public with international cooperation, and public - private partnership with international cooperation. In most cases, the configuration of business models depends on power market structure, and suitable business models support the achievement of high shares of RE. Similarly, a large variety of mechanisms to promote, funding and make RE projects profitable has been identified. Some of them are: national goals, subsidies, trust funds, feedin tariffs, auctions, bids, etc. Table 4 sums up the business models and incentives which are present on small islands. Then, a comparative analysis of the cases is made.

First, a greater private investment differentiates those islands belonging to developed countries in the Atlantic, Mediterranean and Kodiak in the Pacific from the rest of the islands analyzed. It is explained by the liberalization of electricity markets in Europe in 1990, and in the United States in 1992. The goal of this deregulation has been to establish policies to create institutional arrangements to offer more benefits to society such as lower electricity costs, reliable and quality electricity service and building capacities. More competition in the electricity markets of developed countries influences the diversification of the electricity balance which means a greater penetration of RE [131]. Some examples of a high share of RE are:

- Graciosa benefits from a public - private business model. What is interesting about this case is how the payments for the kWh generated are established by a PPA between the public institution, Electricidade dos Azores (EDA) and the private firm, Younicos. Part of the payment is made with the money saved from fuel purchases [132]. Younicos operates as a RESCO (shared savings), a strategy that has allowed it to recoup part of the investment.

- On the Greek island, due to the fragility of isolated systems, certain activities, such as the generation of electricity are still regulated despite the liberalized market (since 1999 in Greece) [113,133]. There, the PPC Renewables S.A. (PPCR) and the Hellenic Electricity Distribution Network Operator (HEDNO Ltd.) were created to install and operate power systems, respectively. Both firms are $100 \%$ owned by the public company Public Power Corporation S.A. (PPC S.A.). ${ }^{20}$ Greece is currently progressing in the deregulation of its electricity market. This has allowed the PPCR to collaborate with private producers to develop RE projects, increase capacities and gain experience in the renewable energy sector. ${ }^{21}$ The participation of private parties has made Ikaria move at a rapid pace to achieve a high RE penetration.

- Kodiak has a public - private - community-based model. It was conceived for the implementation of the Pillar Mountain Wind Project wind farm. The Kodiak Electrical Association (KEA), which is a local non-profit cooperative, has financed the project with a public trust fund and with clean RE bonds (CREBs) issued by Co-Bank. This bank has a financing system for rural public service projects [134]. In KEA, each customer is a co-owner of the company and has active participation in the decision making [135]. It is the only example in which a community is fully involved in RE projects. Indeed, Neves et al. [57] concluded that HRMGs are more successful when the community is involved in the discussion processes, decision making and implementation.

On the other hand, breaking with the statement established in Ref. [131] there are two examples (islands of developed countries) with high RE penetration in spite of the market structure (monopoly): on King Island (Australia), the high share of RE in the electricity mix was due to a public funding (public business model), the quality of regulation, and the technical capacity of the local public and private companies to develop RE projects. Even though the state of Tasmania has a deregulated electricity market, on King Island, the introduction of REs was achieved before 2015 when the electricity market was centralized [131, 136]. Likewise, Necker Island, in the Caribbean, is part of the Commonwealth and is owned by billionaire Richard Branson. Although in this territory the power sector is a monopoly, two private companies: NRG Energy (the largest competitive power generator of the United States) and Virgin Limited Edition, ${ }^{22,23}$ (a company that invests in

\footnotetext{
${ }^{20}$ https://www.deddie.gr/en/deddie/i-etaireia/profil/.

21 https://www.ppcr.gr/en/company/profile-background-strategy.

22 https://www.virginlimitededition.com/en/about-us.

23 The Carbon Warm Room (a non-profit organization founded by Richard Branson) supported this partnership. Available at: https://www.businesswire. com/news/h ome/20140204006598/en/NRG-Energy-Signs-Deal-Virgin-Limited-Edition\# . VMR_pf7F_1Y.
} 


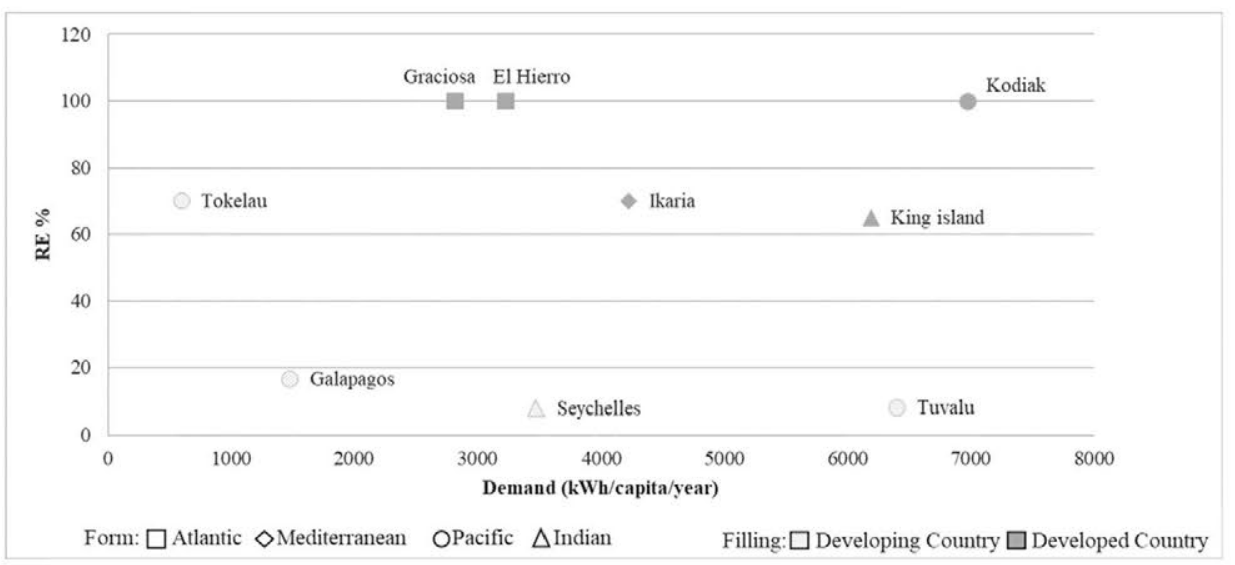

Fig. 1. Renewable energy penetration vs demand per capita.

luxury hotels also owned by Mr. Branson) [123] ${ }^{24}$ partnered to deploy large capacity of RE. Virgin Limited Edition is an example of innovative capacity and adaptability to market needs. This company, which is responsible for renewable power plants, established an agreement with the British Virgin Islands Electricity Corporation - BVIEC, the public company that finances, owns and operates diesel generation. In the British Virgin Islands, the electricity monopoly law passed in 1978 has not been updated to address self-generation and poses a direct barrier to distributed RE [137]. However, a recently launched regulation (2018) is fostering new financing mechanisms to expand RE [138]. Although there is no clear evidence of whether the public sector supported the RE systems. It could be assumed this is a public-private model as both renewables and fuel technologies are operating within a single system. The economic wealth of Virgin Limited Edition and its owner encourages greater private participation.

The electricity markets of the Galapagos Islands ${ }^{25}$ and $\operatorname{SIDS}^{26}$ have tended to be conservative and reflect vertically integrated natural monopolies [35,103,150-152]. In most cases, the market structure has influenced their business models which have been public with international aid. Due to their natural vulnerability and economic situation, international organizations deem that supporting their development with the help of sustainable and safe energy systems is a priority. Only the Pacific SIDS received \$1.5 billion US (2011) from 1970 to 2014 for $\mathrm{RE}$ deployment [31]. This financial assistance has helped to acquire renewable technologies, build national policies, respond to oil prices, achieve high standards of living and compensate trade deficits [34,153]. Nevertheless, this dependency is worrying due to its unfavorable impact on debt accumulation and private investment [31,153], even more, when private investment is being promoted by global policies and the 2030 Agenda. This research agrees with other scientific results [103, 154] which suggest that private investment should grow rather than it being necessarily fostered by international aid. This group of islands, which has ambitious goals, should improve its policies and incentives to

\footnotetext{
${ }^{24}$ The Commonwealth laws require non-resident owners to build a resort on their islands. Otherwise the British government may claim them [51].

${ }^{25}$ In the Galapagos Islands, a public - private partnership was designed to build a wind farm on the island of San Cristobal (2007), the first wind farm in Ecuador. In 2008, the government passed the Constitutional Mandate No. 15 to establish that investments in the generation, transmission and distribution of electricity can only be made by the General State Budget [151,152]. Having a centralized electricity sector, the private funding of renewable projects is limited here, whereas international aid has been strengthened.

${ }^{26}$ The electricity sector in Tuvalu is centralized. A public - private partnership with international cooperation was signed to build a PV system in Funafuti (2006), where the main problem was the lack of skilled workers to undertake the O\&M. TEC, a public company, is in charge of it [49].
}

strengthen the private participation in RE initiatives, and increase local capacities at the institutional and technical levels.

Islands belonging to developed countries are more competitive in the energy sector due to the investment capability of public and private sectors, local capacities, a robust regulatory framework and attractive incentives for business. These factors and others commented on the following section have allowed high shares of RE to be obtained. New challenges for these islands are related to the instability of the power systems which is more acute as renewable generation rises by adding new units. Thus, privatized decision making and new management around the new generation should change to invest in other sectors (such as the research sector) to address solutions to current weaknesses [155]. This involves changes in the design of business models involving research centers. On the other hand, SIDS have not attained an energy identity that reflects their real needs [103] as has happened in the Galapagos Islands. There, innovative business models including private entities are a necessity to decrease the level of dependency on foreign aid, goods and prices. This has to imply the modernization of their power sectors, policies, incentives and stakeholders. To do so, the participation of donors and international financing should be rethought. This means that energy transition requires needs such as building capacities and increasing private participation to be prioritized, especially when financial assistance promotes their companies and local technologies. This is the case of the German companies Lahmeyer and Siemens in the Galapagos Islands ${ }^{27}$ and that of the Arab Masdar Mubadala Company in Tuvalu and Seychelles. These companies take care of the implementation of projects co-financed by the governments of Germany and the Arab Emirates respectively [126,143,149].

This review encourages those experiences in islands from developed countries to be analyzed and identified that could be transferrable to other contexts such as the Galapagos Islands and SIDS. In fact, Ahlgren and Lagerstedt [156] showed that bringing a successful business model from one country to another one could be successful through an in-depth understanding of the new conditions. Future technology developments should reflect the particular conditions of each island [36]. This might promote new ways of collaboration between islands and their partners, where the public sector should be participating as a leader in the introduction of RE.

\section{Configuration of hybrid renewable mini-grids}

Mature technologies have favored the RE sector development

\footnotetext{
${ }^{27}$ In the Galapagos islands: the Baltra PV plant was financed by the Government of Japan and built with Mitsubishi modules, and the PV system of Santa Cruz was financed by Government of Korea and built with BJ Power modules.
} 
Table 4a

\begin{tabular}{|c|c|c|c|c|c|c|c|c|c|c|c|}
\hline \multirow[t]{2}{*}{ Name } & & \multirow[t]{2}{*}{ Project/Kickoff } & \multirow[t]{2}{*}{ Business Model } & \multirow{2}{*}{$\begin{array}{l}\text { Promotion } \\
\text { Tools, Funding } \\
\text { and Viability } \\
\end{array}$} & \multicolumn{3}{|l|}{ Promoters \& Funders } & \multirow[t]{2}{*}{ Initial cost } & \multirow{2}{*}{$\begin{array}{l}\text { Implementing } \\
\text { company }\end{array}$} & \multirow[t]{2}{*}{$O \& M$} & \multirow[t]{2}{*}{ Source } \\
\hline & & & & & Public & Private & Others & & & & \\
\hline $\begin{array}{l}\text { El } \\
\text { Hierro }\end{array}$ & & $\begin{array}{l}\text { Hydroelectric } \\
\text { Power Plant "El } \\
\text { Hierro" (2014) }\end{array}$ & Public - private & $\begin{array}{l}\text { Local goal, } \\
\text { tendering, } \\
\text { auctions, } \\
\text { standard } \\
\text { subsidies }\end{array}$ & $\begin{array}{l}\text { Canary Islands Council } \\
\text { (Municipality of Porto Novo), } \\
\text { Technological Institute of the } \\
\text { Canary Islands (ITC), Institute } \\
\text { for Diversification and Saving } \\
\text { of Energy (IDAE) }\end{array}$ & Endesa Ltd. & & $\begin{array}{l}\$ 93 \\
\text { million US }\end{array}$ & $\begin{array}{l}\text { Gorona del } \\
\text { Viento El Hierro } \\
\text { Ltd. }\end{array}$ & $\begin{array}{l}\text { Gorona del } \\
\text { Viento El Hierro } \\
\text { Ltd. }\end{array}$ & $\begin{array}{l}{[23,78} \\
139 \\
140]\end{array}$ \\
\hline Graciosa & & $\begin{array}{l}\text { The Graciosa } \\
\text { Project }\end{array}$ & Public - private & $\begin{array}{l}\text { Local and } \\
\text { national goal, } \\
\text { PPA, grants }\end{array}$ & $\begin{array}{l}\text { Entidade Reguladora dos } \\
\text { Servicios Energéticos (ERSE) } \\
\text { (guarantees payments and } \\
\text { decides PPAs), EDA (energy } \\
\text { sales), Agency for the } \\
\text { Promotion of Investment in the } \\
\text { Azores (APIA) }\end{array}$ & Younicos AG & & $\begin{array}{l}\$ 27 \\
\text { million US }\end{array}$ & Younicos AG & $\begin{array}{l}\text { Maintenance } \\
\text { Agreement (not } \\
\text { available } \\
\text { details) }\end{array}$ & $\begin{array}{l}{[132,} \\
141]\end{array}$ \\
\hline Tokelau & & TREP (2012) & $\begin{array}{l}\text { Public with } \\
\text { international } \\
\text { cooperation }\end{array}$ & National Goal & Government of Tokelau & & $\begin{array}{l}\text { The New Zealand } \\
\text { Ministry of Foreign } \\
\text { Affairs and Trade } \\
\text { (MFAT) }\end{array}$ & $\begin{array}{l}\$ 6.93 \\
\text { million US }\end{array}$ & $\mathrm{N} / \mathrm{A}$ & $\begin{array}{l}\text { Department of } \\
\text { Energy (DoE), } \\
\text { Taupulegas }\end{array}$ & $\begin{array}{l}{[23,48,} \\
121]\end{array}$ \\
\hline \multirow[t]{3}{*}{ Tuvalu } & Funafuti & $\begin{array}{l}\text { The Tuvalu Solar } \\
\text { Power Project } \\
\text { (2006) }\end{array}$ & $\begin{array}{l}\text { Public - private } \\
\text { with } \\
\text { international } \\
\text { cooperation }\end{array}$ & National Goal & $\begin{array}{l}\text { Ministry of Public Utilities, The } \\
\text { Tuvalu Electricity Corporation } \\
\text { (TEC) }\end{array}$ & $\begin{array}{l}\text { The Kansai Electric } \\
\text { Power Company, e8 } \\
\text { Secretariat, Tokyo } \\
\text { Electric Power } \\
\text { Company (TEPCO) }\end{array}$ & $\begin{array}{l}\text { Government of Japan, } \\
\text { Pacific Power } \\
\text { Association (PPA) }\end{array}$ & $\mathrm{N} / \mathrm{A}$ & $\begin{array}{l}\text { Japanese } \\
\text { Sumitomo } \\
\text { Densetsu } \\
\text { Company }\end{array}$ & TEC & $\begin{array}{l}{[49,} \\
142]\end{array}$ \\
\hline & & $\begin{array}{l}\text { Solar Space } \\
\text { Creation Project } \\
\text { (2015) }\end{array}$ & $\begin{array}{l}\text { Public with } \\
\text { international } \\
\text { cooperation }\end{array}$ & National Goal & Government of Tuvalu & & $\begin{array}{l}\text { United Arab Emirates } \\
\text { (UAE) -Pacific } \\
\text { Partnership Fund, } \\
\text { Abu Dhabi Fund for } \\
\text { Development (ADFD) }\end{array}$ & $\begin{array}{l}\$ 50 \\
\text { million US }\end{array}$ & $\begin{array}{l}\text { Masdar } \\
\text { Mubadala } \\
\text { Company }\end{array}$ & TEC & $\begin{array}{l}{[23,49} \\
143 \\
144]\end{array}$ \\
\hline & Vaitupu & $\begin{array}{l}\text { The Tuvalu } \\
\text { Photovoltaic } \\
\text { Electricity Network } \\
\text { Integration Project } \\
\text { (2009) }\end{array}$ & $\begin{array}{l}\text { Public with } \\
\text { international } \\
\text { cooperation }\end{array}$ & National Goal & $\begin{array}{l}\text { Government of Tuvalu, TEC, } \\
\text { Tuvalu Department of Energy }\end{array}$ & & $\begin{array}{l}\text { Government of Italy } \\
\text { and Austria, } \\
\text { International Union } \\
\text { for Conservation of } \\
\text { Nature (IUCN) }\end{array}$ & $\begin{array}{l}\$ 800,000 \\
\text { US }\end{array}$ & $\mathrm{N} / \mathrm{A}$ & TEC & {$[23,49]$} \\
\hline
\end{tabular}


Table 4b

\begin{tabular}{|c|c|c|c|c|c|c|c|c|c|c|c|}
\hline \multirow[t]{2}{*}{ Name } & & \multirow[t]{2}{*}{ Project/Kickoff } & \multirow[t]{2}{*}{ Business Model } & \multirow{2}{*}{$\begin{array}{l}\text { Promotion Tools, } \\
\text { Funding and } \\
\text { Viability }\end{array}$} & \multicolumn{3}{|l|}{ Promoters \& Funders } & \multirow{2}{*}{$\begin{array}{l}\text { Initial } \\
\text { cost }\end{array}$} & \multirow[t]{2}{*}{ Implementing company } & \multirow[t]{2}{*}{$O \& M$} & \multirow[t]{2}{*}{ Source } \\
\hline & & & & & Public & Private & Others & & & & \\
\hline \multirow[t]{6}{*}{ Galapagos } & $\begin{array}{l}\text { San } \\
\text { Cristobal }\end{array}$ & $\begin{array}{l}\text { Wind farm San } \\
\text { Cristobal (2007) }\end{array}$ & $\begin{array}{l}\text { Public - private } \\
\text { with } \\
\text { international } \\
\text { cooperation }\end{array}$ & $\begin{array}{l}\text { National Goal, trust } \\
\text { fund, voluntary } \\
\text { donations from } \\
\text { taxes, Clean } \\
\text { Development } \\
\text { Mechanism (CDM) } \\
\text { (2008), feed-in } \\
\text { tariff, subsidies }\end{array}$ & $\begin{array}{l}\text { Ministry of Electricity and } \\
\text { Renewable Energy } \\
\text { (MEER), Provincial } \\
\text { Electricity Company } \\
\text { Galapagos } \\
\text { ELECGALAPAGOS, } \\
\text { Municipality of San } \\
\text { Cristobal }\end{array}$ & $\begin{array}{l}\text { Global } \\
\text { Sustainable } \\
\text { Electricity } \\
\text { Partnership } \\
\text { (GSEP) }\end{array}$ & $\begin{array}{l}\text { United Nations } \\
\text { Foundation (UNF), } \\
\text { United Nation } \\
\text { Development Program } \\
\text { (UNDP) }\end{array}$ & $\begin{array}{l}\$ 10 \\
\text { million } \\
\text { Us }\end{array}$ & $\begin{array}{l}\text { EOLICSA (today part of } \\
\text { ELECGALAPAGOS), } \\
\text { UNPD }\end{array}$ & ELECGALAPAGOS & {$[82]^{\mathrm{a}}$} \\
\hline & $\begin{array}{l}\text { Santa } \\
\text { Cruz - } \\
\text { Baltra }\end{array}$ & $\begin{array}{l}\text { Wind farm Baltra } \\
\text { and the } \\
\text { transmission line } \\
\text { Baltra - Santa } \\
\text { Cruz (2015) }\end{array}$ & $\begin{array}{l}\text { Public with } \\
\text { international } \\
\text { cooperation }\end{array}$ & $\begin{array}{l}\text { National Goal, } \\
\text { MDL, trust fund }\end{array}$ & $\begin{array}{l}\text { MEER, ELECGALAPAGOS, } \\
\text { Electricity Corporation of } \\
\text { Ecuador (CELEC-EP) } \\
\text { through the business unit } \\
\text { Transelectric }\end{array}$ & & $\begin{array}{l}\text { Global Environment } \\
\text { Facility (GEF), UNF, } \\
\text { UNDP, Germany } \\
\text { International } \\
\text { Cooperation Agency } \\
\text { (GIZ) }\end{array}$ & $\begin{array}{l}\$ 27.66 \\
\text { million } \\
\text { Us }\end{array}$ & $\begin{array}{l}\text { MEER, CELEC-EP, } \\
\text { ELECGALAPAGOS, } \\
\text { UNDP, Unison - } \\
\text { LeoKonKorea }\end{array}$ & ELECGALAPAGOS & [126] \\
\hline & & $\begin{array}{l}\text { Photovoltaic } \\
\text { Project Puerto } \\
\text { Ayora (2014) }\end{array}$ & $\begin{array}{l}\text { Public with } \\
\text { international } \\
\text { cooperation }\end{array}$ & National Goal & MEER, ELECGALAPAGOS & & $\begin{array}{l}\text { Korea International } \\
\text { Cooperation Agency } \\
\text { (KOICA) }\end{array}$ & $\begin{array}{l}\$ 10.6 \\
\text { million } \\
\text { US }\end{array}$ & $\begin{array}{l}\text { MEER, } \\
\text { ELECGALAPAGOS, } \\
\text { KOICA }\end{array}$ & ELECGALAPAGOS & [145] \\
\hline & & $\begin{array}{l}\text { Photovoltaic } \\
\text { System with } \\
\text { storage batteries } \\
\text { in Baltra (2016) }\end{array}$ & $\begin{array}{l}\text { Public with } \\
\text { international } \\
\text { cooperation }\end{array}$ & National Goal & MEER, ELECGALAPAGOS & & $\begin{array}{l}\text { Japan International } \\
\text { Cooperation Agency } \\
\text { (JICA) }\end{array}$ & $\begin{array}{l}\$ 10 \\
\text { million } \\
\text { Us }\end{array}$ & $\begin{array}{l}\text { MEER, } \\
\text { ELECGALAPAGOS, JICA }\end{array}$ & ELECGALAPAGOS & [126] \\
\hline & Isabela & $\begin{array}{l}\text { Hybrid System } \\
\text { Isabela (ongoing) }\end{array}$ & $\begin{array}{l}\text { Public with } \\
\text { international } \\
\text { cooperation }\end{array}$ & National Goal & MEER, ELECGALAPAGOS & & $\begin{array}{l}\text { Government of } \\
\text { Germany through the } \\
\text { German Development } \\
\text { Bank-KfW }\end{array}$ & $\begin{array}{l}\$ 11.5 \\
\text { million } \\
\text { Us }\end{array}$ & $\begin{array}{l}\text { MEER, } \\
\text { ELECGALAPAGOS, } \\
\text { KfW, Lahmeyer } \\
\text { International Ltd., } \\
\text { Siemens Ltd. and } \\
\text { Siemens AG }\end{array}$ & ELECGALAPAGOS & [145] \\
\hline & Floreana & $\begin{array}{l}\text { Hybrid electricity } \\
\text { generation } \\
\text { system (diesel, } \\
\text { biodiesel and } \\
\text { photovoltaic } \\
\text { energy in } \\
\text { Floreana (2011) }\end{array}$ & $\begin{array}{l}\text { Public with } \\
\text { international } \\
\text { cooperation }\end{array}$ & $\begin{array}{l}\text { National Goal, trust } \\
\text { fund }\end{array}$ & $\begin{array}{l}\text { MEER, ELECGALAPAGOS, } \\
\text { National Institute for } \\
\text { Agricultural Research } \\
\text { (INIAP) }\end{array}$ & & $\begin{array}{l}\text { UNDP, German Federal } \\
\text { Ministry for the } \\
\text { Environment, Nature } \\
\text { Conservation, Building } \\
\text { and Nuclear Safety } \\
\text { (BMU), GIZ, Inter- } \\
\text { American Institute for } \\
\text { Cooperation on } \\
\text { Agriculture (IICA) }\end{array}$ & $\mathrm{N} / \mathrm{A}$ & $\begin{array}{l}\text { MEER, } \\
\text { ELECGALAPAGOS, } \\
\text { UNDP, ICA }\end{array}$ & ELECGALAPAGOS & $\begin{array}{l}{[126,} \\
146]\end{array}$ \\
\hline
\end{tabular}


Table 4c

Business models for renewable energy.

\begin{tabular}{|c|c|c|c|c|c|c|c|c|c|c|}
\hline \multirow[t]{2}{*}{ Name } & \multirow{2}{*}{$\begin{array}{l}\text { Project/ } \\
\text { Kickoff }\end{array}$} & \multirow{2}{*}{$\begin{array}{l}\text { Business } \\
\text { Model }\end{array}$} & \multirow{2}{*}{$\begin{array}{l}\text { Promotion } \\
\text { Tools, Funding } \\
\text { and Viability }\end{array}$} & \multicolumn{3}{|c|}{ Promoters \& Funders } & \multirow{2}{*}{$\begin{array}{l}\text { Initial } \\
\text { cost }\end{array}$} & \multirow{2}{*}{$\begin{array}{l}\text { Implementing } \\
\text { company }\end{array}$} & \multirow[t]{2}{*}{$O \& M$} & \multirow[t]{2}{*}{ Source } \\
\hline & & & & Public & Private & Others & & & & \\
\hline Kodiak & $\begin{array}{l}\text { Pillar } \\
\text { Mountain } \\
\text { Project } \\
\text { (Wind farm) } \\
\text { (2009 and } \\
2012 \text { ) }\end{array}$ & $\begin{array}{l}\text { Public- } \\
\text { private - } \\
\text { community- } \\
\text { based }\end{array}$ & $\begin{array}{l}\text { National Goal, } \\
\text { clean RE bonds } \\
\text { (CREBs), trust } \\
\text { fund, subsidies }\end{array}$ & $\begin{array}{l}\text { Alaska } \\
\text { Energy Authority }\end{array}$ & $\begin{array}{l}\text { KEA, Co- } \\
\text { Bank, } \\
\text { Younicos } \\
\text { AG }\end{array}$ & Community & $\begin{array}{l}\$ 59 \\
\text { million } \\
\text { US }\end{array}$ & $\begin{array}{l}\text { KEA, Younicos } \\
\text { AG }\end{array}$ & $\begin{array}{l}\text { KEA, } \\
\text { Younicos AG }\end{array}$ & $\begin{array}{l}\text { [106, } \\
134]^{b}\end{array}$ \\
\hline Necker & $\begin{array}{l}\text { Necker } \\
\text { Island } \\
\text { Project } \\
\text { (2014) }\end{array}$ & Public-private & $\begin{array}{l}\text { Local goal, } \\
\text { bids, Request } \\
\text { for Proposal } \\
\text { (RFP) }\end{array}$ & BVIEC & $\begin{array}{l}\text { Virgin } \\
\text { Limited } \\
\text { Edition, } \\
\text { NRG } \\
\text { Energy }\end{array}$ & & N/A & NRG Energy & $\begin{array}{l}\text { NRG Energy, } \\
\text { BVIEC }\end{array}$ & $\begin{array}{l}{[51,} \\
123]\end{array}$ \\
\hline Ikaria & $\begin{array}{l}\text { Hybrid } \\
\text { Energy } \\
\text { Project } \\
(2012)\end{array}$ & Public private & $\begin{array}{l}\text { National Goal, } \\
\text { fund, feed in } \\
\text { tariff }\end{array}$ & $\begin{array}{l}\text { PPC Ltd.., PPC } \\
\text { Renewables Ltd. } \\
\text { (PPCR) }\end{array}$ & N/A & & $\begin{array}{l}\$ 46 \\
\text { million } \\
\text { US }\end{array}$ & $\begin{array}{l}\text { PPCR Ltda., } \\
\text { other private } \\
\text { partners }\end{array}$ & HEDNO Ltd. & $\begin{array}{l}{[113,} \\
147, \\
148]^{\mathrm{c}}\end{array}$ \\
\hline $\begin{array}{l}\text { King } \\
\text { Island }\end{array}$ & $\begin{array}{l}\text { KIREIP } \\
(1998, \\
2003,2008 \\
\text { and 2014) }\end{array}$ & Public & $\begin{array}{l}\text { National Goal, } \\
\text { subsidies, } \\
\text { government } \\
\text { taxes on coal } \\
\text { (July } 2012 \text { and } \\
2014 \text { ) }\end{array}$ & $\begin{array}{l}\text { Government of } \\
\text { Australia and } \\
\text { Tasmania, Hydro } \\
\text { Tasmania, } \\
\text { Australian } \\
\text { Renewable } \\
\text { Energy Agency } \\
\text { (ARENA) }\end{array}$ & & & $\begin{array}{l}\$ 22 \\
\text { million } \\
\text { US }\end{array}$ & $\begin{array}{l}\text { Hydro } \\
\text { Tasmania, } \\
\text { Entura, } \\
\text { Momentum } \\
\text { energy }\end{array}$ & $\begin{array}{l}\text { Hydro } \\
\text { Tasmania }\end{array}$ & $\begin{array}{l}{[23,} \\
51, \\
114]^{d}\end{array}$ \\
\hline Seychelles & $\begin{array}{l}\text { Port } \\
\text { Victoria } \\
\text { Wind Farm } \\
(2014)\end{array}$ & $\begin{array}{l}\text { Public with } \\
\text { international } \\
\text { cooperation }\end{array}$ & National Goal & $\begin{array}{l}\text { Government of } \\
\text { Seychelles }\end{array}$ & & $\begin{array}{l}\text { UAE-Pacific } \\
\text { Partnership } \\
\text { Fund, ADFD }\end{array}$ & $\begin{array}{l}\$ 28 \\
\text { million } \\
\text { US }\end{array}$ & $\begin{array}{l}\text { Masdar } \\
\text { Mubadala } \\
\text { Company }\end{array}$ & $\begin{array}{l}\text { Public } \\
\text { Utilities } \\
\text { Corporation } \\
\text { (PUC) }\end{array}$ & $\begin{array}{l}{[23,} \\
149]^{\mathrm{e}}\end{array}$ \\
\hline
\end{tabular}

${ }^{\text {a }}$ http://www.gsep-ppp.org/case-studies/san-cristobal-galapagos-wind-power-project/.

b https://www.hydroworld.com/articles/2009/03/alaska-electric-association-buys-225-mw-terror-lake.html.

c https://www.mfa.gr/cyprus/en/about-greece/energy-and-environment/energy.html.

d http://www.entura.com.au/projects/7753/. https://www.smh.com.au/business/renewable-energy-trial-provides-tasmania-with-free-power-20171117-gznwk7. html. http://www.kingislandrenewableenergy.com.au/project-information/overview.

e http://www.puc.sc/about-our-network/.

globally. In the islands analyzed, the processes of hybridization of thermal power plants with renewable resources began more than a decade ago. Table 5 shows the installed capacity of diesel, RE and the storage system per island as well as indicators, such as RE penetration, energy consumption and peak demand (data that have been commented in previous sections). The renewable capacity of the case studies represents a minimal part of the wind and solar global potential estimated in Ref. [17], $0.3 \%$ and $0.08 \%$ respectively.

Thanks to this state of the art, it is possible to identify that, on small islands, the most common technologies to hybridize DGs are wind and PV with electromechanical batteries. In the last decade, wind and solar power have increased their penetration in many power systems due to their lower cost $[157,158]$. In the islands studied, the greatest installed renewable capacity is wind energy because of the availability of the resource, especially on the islands in the Atlantic. Furthermore, this is the result of its economic competitiveness in comparison with traditional diesel technology [57]. PV has a greater presence on the Pacific islands and hydroelectric power plants on islands with high elevations (between 1000 and $1500 \mathrm{~m}$ ). In most cases, installing more than one RE technology, storage and control system helps HRMGs to compensate the RE intermittency and seasonality, and the imbalance between supply and demand. On those islands in which these three elements are combined, the penetration of RE is higher (between 60 and 100\%).

The type of technology used for the hybridization of thermal systems depends mainly on the geographical and geological characteristics and on the natural resources of the region. However, these preconditions are not enough in the case of hydroelectric generation even more so when it has an associated pumped storage system: technological research, investment and local capacities have greater weight than in other cases. In SIDS and the Galapagos Islands, the technology used also depends on the technology manufactured in the country of origin of international aid.
Some examples are described below:

The hybrid system on El Hierro consists of five wind turbines of 2.3 MW each, a hydroelectric power plant with four Pelton turbines of $2.8 \mathrm{MW}$, a pumping station of $6 \mathrm{MW}$ (to pump desalinated water), ${ }^{28}$ and a thermal power plant of $11.36 \mathrm{MW}$ (it is used as a backup system) [78]. Pumped storage helps power systems to achieve high wind penetration [157]. This hybrid system has generated over a thousand hours of $100 \%$ RE ( $48 \mathrm{GWh} /$ year) since its start-up: each hour represents a saving of 1765 liters of diesel and avoids the emission of 3 tons of $\mathrm{CO}_{2}$ into the atmosphere [159]. In recent years, RE has increased due to improvements in control strategies to regulate frequency deviations [160]. The pumped hydro, wind and control systems have cost $\$ 3230$ US/installed $\mathrm{kW}$ (see Table $4 \mathrm{a}, 5$ ), a high value for a relatively small system which reflects that this project would not be possible without public and private financing [36] and the support of the Technological Institute of the Canary Islands. Nowadays, the maintenance costs of the wind/hydro power-system are four times cheaper than a diesel generation system [78]. It is worth mentioning that the Canary Islands government has been working on water desalination for more than 50 years. This water

\footnotetext{
${ }^{28}$ The surplus of wind energy is used to pump desalinated water from the lower reservoir, with a capacity of $150,000 \quad \mathrm{~m}<\mathrm{span}$ data-format $=$ "superscript" $>3</$ span $>$, to the upper one, a natural crater called La Caldera, with a capacity of $380,000 \mathrm{~m}<$ span data-format="superscript" $>3<$ / span $>$. Both reservoirs are connected through a $3 \mathrm{~km}$ long pipe. $530 \mathrm{~m}$ of pipeline are buried to preserve $\mathrm{El} \mathrm{Cardonal,} \mathrm{a} \mathrm{protected} \mathrm{area} \mathrm{with} \mathrm{a} \mathrm{great} \mathrm{value}$ for local islanders [79].
} 
Table 5

Configuration of hybrid mini-grids

\begin{tabular}{|c|c|c|c|c|c|c|c|c|c|c|c|c|c|c|}
\hline \multirow[t]{2}{*}{ Name } & & \multirow[t]{2}{*}{$\begin{array}{l}\text { Wind } \\
\text { (MW) }\end{array}$} & \multirow[t]{2}{*}{$\begin{array}{l}\text { Photovoltaic } \\
\text { (MWp) }\end{array}$} & \multirow[t]{2}{*}{$\begin{array}{l}\text { Hydroelectric } \\
\text { (MW) }\end{array}$} & \multirow[t]{2}{*}{$\begin{array}{l}\text { Pumping } \\
\text { (MW) }\end{array}$} & \multirow[t]{2}{*}{$\begin{array}{l}\text { Diesel } \\
\text { (MW) }\end{array}$} & \multirow[t]{2}{*}{$\begin{array}{l}\text { Biodiesel } \\
\text { (MW) }\end{array}$} & \multirow{2}{*}{$\begin{array}{l}\text { Batteries (Pb, } \\
\text { lead-acid) } \\
\text { (Li, lithium- } \\
\text { ion)/Flywheel }\end{array}$} & \multirow{2}{*}{$\begin{array}{l}\text { Total } \\
\text { Power } \\
\text { (MW) }\end{array}$} & \multirow[t]{2}{*}{$\mathrm{RE}(\%)$} & \multicolumn{3}{|l|}{ Demand } & \multirow[t]{2}{*}{ Source } \\
\hline & & & & & & & & & & & $\begin{array}{l}\text { (MWh/ } \\
\text { year) }\end{array}$ & $\begin{array}{l}\text { (kWh/ } \\
\text { capita/ } \\
\text { year) }\end{array}$ & $\begin{array}{l}\text { Peak } \\
\text { demand } \\
(M W)\end{array}$ & \\
\hline El Hierro & & 11.5 & & $\begin{array}{l}11.3 \\
\text { (Desalination) }\end{array}$ & 6 & 11.36 & & & 34.16 & $70-100$ & 48,000 & 3232.54 & 7.6 & $\begin{array}{l}{[51,78,139,} \\
159]\end{array}$ \\
\hline Graciosa & & 4.5 & 1 & & & 4.61 & & $4 \mathrm{MW} / 3.2 \mathrm{MWh}$ & 10.11 & $70-100$ & 14,000 & 2819.17 & 3 & $\begin{array}{l}{[132,141,} \\
180]\end{array}$ \\
\hline \multirow[t]{3}{*}{ Tokelau } & Fakaofo & & 0.365 & & & $\mathrm{~N} / \mathrm{A}$ & & $\mathrm{Pb} 3.37 \mathrm{MWh}$ & 1 & 70 & 255.1 & 479.80 & 0.0512 & {$[40,48,95$} \\
\hline & Atafu & & 0.3 & & & $\mathrm{~N} / \mathrm{A}$ & & $\mathrm{Pb} 2.76 \mathrm{MWh}$ & & & 201.8 & & 0.038 & 121,127, \\
\hline & Nukunomu & & 0.265 & & & N/A & & $\mathrm{Pb} 2.45 \mathrm{MWh}$ & & & 219.4 & & 0.0367 & 181] \\
\hline \multirow[t]{3}{*}{ Tuvalu } & Funafuti & & $2.065^{\mathrm{a}}$ & & & 2345 & & & 4.87 & 8.2 & 6400 & 593.58 & 0.936 & {$[49,127$,} \\
\hline & Vaitupu & & & & & 0.26 & & & & & & & & $142,143]$ \\
\hline & Others & & & & & $0.13-0.201$ & & & & & & & & \\
\hline \multirow[t]{4}{*}{ Galapagos } & San Cristobal & 2.4 & & & & 8.3 & & & 10.7 & 8.2 & 14,400 & 1475.19 & $3.37(2016)$ & {$[126,177$,} \\
\hline & Santa Cruz - Baltra & 2.25 & 1.567 & & & 13.9 & & $\begin{array}{l}\mathrm{Pb} 4 \mathrm{MWh} \\
\mathrm{Li} 0.268 \mathrm{MWh}\end{array}$ & 17.71 & 20 & 27,850 & & $9.28(2016)$ & $182,183]$ \\
\hline & Isabela & & 0.952 & & & 2.3 & & $\begin{array}{l}\text { Li } 0.66 \mathrm{MW} / \\
0.33 \mathrm{MWh}\end{array}$ & 3.25 & $\mathrm{~N} / \mathrm{A}$ & 4540 & & $1(2016)$ & \\
\hline & Floreana & & 0.21 & & & 0.15 & 0,138 & $\mathrm{~Pb} 0.096 \mathrm{MWh}$ & 0.31 & 57 & 197 & & $\begin{array}{l}0.076 \\
(2016)\end{array}$ & \\
\hline Kodiak & & 9 & & $\begin{array}{l}11,5 \\
\text { (Lakewater) }\end{array}$ & & 33 & & $\begin{array}{l}3 \mathrm{MW} / \\
0.75 \mathrm{MWh}\end{array}$ & 53.5 & 100 & 94,800 & 6976.46 & 27 & $\begin{array}{l}{[106,134,} \\
184]^{b}\end{array}$ \\
\hline Necker & & 0.9 & 0.3 & & & 0.96 & & $0.5 \mathrm{MWh}$ & 2.16 & 80 & N/A & - & 0.4 & {$[51,123]$} \\
\hline Ikaria & & 2.7 & 1.04 & $\begin{array}{l}4.15 \\
\text { (Rainwater) }\end{array}$ & 3 & 12.16 & & & 23.05 & $60-70$ & 29,000 & 4221.87 & $9(2012)$ & $\begin{array}{l}{[113,133,} \\
148,185]\end{array}$ \\
\hline King Island & & 2.4 & 0.1 & & & 6 & $\mathrm{~N} / \mathrm{A}$ & $\begin{array}{l}\mathrm{Pb} 3 \mathrm{MW} / \\
1.5 \mathrm{MWh} \\
\text { Flywheels - } \\
\text { 2MVA }\end{array}$ & 8.55 & 65 & 12,000 & 6191.75 & 2.5 & $\begin{array}{l}{[23,51,} \\
124]\end{array}$ \\
\hline \multirow[t]{2}{*}{ Seychelles } & $\begin{array}{l}\text { Mahé (Romainville, } \\
\text { lle du Port) }\end{array}$ & 6 & & & & 71 & & & 77 & 8 & 324,300 & 3472.16 & 50 & $\begin{array}{l}{[52,100,} \\
149]\end{array}$ \\
\hline & Praslin - La Digue & & & & & 13 & & & 13 & & & & 7 & \\
\hline
\end{tabular}

${ }^{\text {a }}$ Total renewable capacity installed in Tuvalu. Available at: https://islands.irena.org/RE-Progress/Country-Profiles.

b http://www.kodiakelectric.com/generation.html. 
is for human consumption, agriculture and electricity production [161] .${ }^{29}$ On the island of El Hierro, there are four public desalination plants, whose electricity consumption is $9 \%$ of the total demand [162,163]. In contrast, the island of San Cristobal (Galapagos) has a hydro-potential of $140 \mathrm{~m}^{3}$ /year in El Cerro Gato (lakewater) [164], but the national government has not been able to assess the technical feasibility of a pump-storage system due to the lack of financing and the difficulties in establishing agreements with local institutions. ${ }^{30}$ In San Cristobal, the wind farm alone has cost $\$ 4200$ US/installed kW (see Table 4b, 5), $14 \%$ more than on El Hierro. Furthermore, there are no robust control and storage systems. The result is a low RE penetration (8.2\%).

Zakeri and Syri [165] found the cost per unit of power capacity of storage systems such as pumped, flywheel, lithium-ion and lead-acid batteries is $\$ 583, \$ 326, \$ 526, \$ 430$ US $/ \mathrm{kW}$ respectively, while the storage cost is $\$ 77$ US/kWh of pumped, $\$ 903$ US/kWh of lithium-ion, and $\$ 702$ US $/ \mathrm{kWh}$ of lead-acid. Nevertheless, the storage cost of flywheels and batteries is falling to levels much closer to pumped storage systems $[36,165,166]$. In terms of LCOE, pumped storage is the cheapest option ( $\$ 136$ US/MWh) [165]. In islands where it is not possible to install pumped storage plants, batteries are the low-cost alternative [36], such as the case of Tokelau and Tuvalu. Several studies have concluded how energy power systems reduce $\mathrm{LCOE}$ and $\mathrm{CO}_{2}$ emissions using RE sources and batteries in comparison with DGs only scenarios [46,167-170]. Batteries may lead to a substantial cost reduction especially in islands with a high irradiation [46]. HRMGs, which use PV technology, open up a higher introduction of electromechanical storage systems due to the energy surplus related to its daily solar irradiance profile [171]. On small islands worldwide, with a potential of $5 \mathrm{GWh}$ of battery capacity, the RE share can increase from $46 \%$ to $70 \%$ and the LCOE may decrease from $40 \mathrm{USc} / \mathrm{kWh}$ to $6 \%$ lower [46]. However, the environmental benefits related to the use of batteries could be minimized by inadequate battery waste treatment. These storage systems require the use of quality control systems to extend their lifetime. Furthermore, the introduction of waste management programs is necessary to collect, replace and recycle batteries [172]. In developed countries, lead acid batteries are entirely recycled, but this is costly and more difficult to implement in less developed economies [173]. Circular economy practices are expected to become more important in the future to solve this issue. Business model implementation is also necessary to support the return of batteries at the end of their lifetime [174].

In the Galapagos Islands, the only storage systems installed are batteries. For instance, Santa Cruz has a PV system of $1.5 \mathrm{MWp}$ and a thermal system of $13.9 \mathrm{MW}$ and Baltra has a PV system of $67 \mathrm{kWp}$, a wind farm of $2.5 \mathrm{MW}^{31}$ and a battery storage system of $4.3 \mathrm{MWh}$ [126, 175]. Santa Cruz and Baltra are interconnected through a $51.4 \mathrm{~km}$ cable. ${ }^{32}$ The storage system is hybrid and very innovative technologically [176]. The lead-acid batteries (4.03 MWh) store the surplus energy generated by the wind farm and the PV systems, and the lithium-ion batteries $(0.268 \mathrm{MWh})$ regulate the wind-generated electricity fluctuations [126]. Today, $20 \%$ of the electricity generated by the full power system described is renewable, which amounts to an annual saving of approximately 2.6 million liters/year and avoids the emission of 5150 tons of $\mathrm{CO}_{2}$ into the atmosphere $[177,178]$.

Flywheels are fast-responding (milliseconds or seconds to minutes) which make them suitable for hybrid power systems [165]. For example, on King Island, the power system consists of $6 \mathrm{MW}$ of thermal generators

\footnotetext{
29 http://www.gobiernodecanarias.org/noticias/agpa/Aguas/24759/canarias -319-desaladoras-capacidad-produccion-agua-potable-superior-660.000-m-dia.

${ }^{30}$ From an interview with technical assistants of Renewable Energy Directorate of Ministry of Electricity and Renewable Energy from Ecuador (October 2018).

${ }^{31}$ It is made up of three wind turbines of $750 \mathrm{~kW}$ each one [127].

${ }^{32}$ It includes an submarine cable of $900 \mathrm{~m}$ that crosses the Itabaca channel [127].
}

(diesel and biodiesel), 2.24 MW of wind turbines, $0.1 \mathrm{MWp}$ of PV, a resistive load of $1.5 \mathrm{MW}$ that can vary rapidly to absorb the surplus wind-generated electricity, and two flywheels ${ }^{33}$ whose performance is even higher through a $1.5 \mathrm{MWh}$ battery bank [51,124]. In fact, a battery-flywheel system can increase the battery's lifetime significantly [179]. Thanks to this architecture, the island has managed to reduce electricity service interruptions by $50 \%$ and save over 21 million liters of diesel and about $\$ 1,8$ million US/year in O\&M and fuel purchases [23].

Technological breakthroughs make it possible for the islands to overcome those problems related to geography, geology, seasonality of renewable resources and use of water and land, stability of electricity service, O\&M costs and high electricity prices. Even though the Pacific SIDS $^{34}$ are flat and small, and have a high-density population, and the Seychelles ${ }^{35}$ have orography constraints (mountainous and granite islands) that prevent the access of heavy machinery to the interior, both groups of islands have installed energy systems that require a large amount of land. Achieving high RE penetration is limited by the lack of capacities and financing but not by technology. On the islands analyzed in the Pacific and Indian Oceans, according to the data on the currently installed capacity, there is only hybridized $25 \%$ of the total diesel generation (150 MW).

Although the technical objective of the introduction of RE is to use DGs as a backup, Tuvalu, the Galapagos Islands, and the Seychelles are still using DGs as the main generation source. These islands need more reliable control and storage systems that are capable of storing RE for several hours and days. An example would be pumped hydroelectric storage if geographical conditions make it possible [57] (e.g., San Cristobal - the Galapagos Islands). On these islands where only desalinated water may be used for pumping systems, there are two main barriers: the initial investment capacity and the large amount of electricity needed to desalinate the water. The most commonly used storage systems are lead-acid battery banks (less costly than lithium-batteries), and flywheels are only used on one island. The islands in the Pacific and Indian Oceans have a great opportunity to further strengthen mini-grids with a bigger renewable and storage capacity. In order to do so, building capacities and accessing funding are a challenge as well as a priority.

\section{Results and discussion}

\subsection{Overview of business models}

In island areas where energy is generated with HRMGs, business models define the way these systems are financed, initiated, planned,

\footnotetext{
${ }^{33}$ It allows, on the one hand, the storage of the surplus of wind energy in the form of kinetic energy that will be used as electricity when needed, and on the other hand, starting the secondary DG swiftly if the demand is higher than the renewable generation can produce. That way the system stability is guaranteed and shutdowns are avoided.

${ }^{34}$ In Tokelau, the TREP has achieved 0.93 MWp of installed PV capacity and battery banks of $8.58 \mathrm{MWh}$. The configuration of this system has allowed maintenance costs to be reduced from $\$ 85,000$ US/year to $\$ 42,000$ US/year, a saving of $\$ 829,000$ US/year in the purchase of fuel and avoiding the annual emission of 1300 tons of $\mathrm{CO}_{2}$ to the environment $[23,96]$. Before the implementation of the TREP, in 2011 Tokelau imported 162,000 liters of diesel: 160, 000 liters were used to generate electricity and the remainder, in the transport sector. Nowadays, fuel imports are mostly destined to the transport sector (diesel and gasoline) and for cooking stoves (kerosene) [48].

${ }^{35}$ In the Seychelles, the construction of a wind farm with eight wind turbines ( 0.75 MW each): five on Romainville and three on Ile du Port (two artificial islands on the coast of Mahé) [150]. Mahé is interconnected with the rest of the islands (Praslin, La Digue, Romainville, Ile du Port) by means of a submarine cable connection $[23,101]$. Thanks to this project, the Seychelles import 1.5 million liters of diesel per year less and prevent the emission of 10,000 tons of $\mathrm{CO}_{2}$ [150].
} 
implemented and operated [186]. Unlike business models applied in rural areas, in terms of funding, this research has identified five business models applied on non-interconnected small islands: one public and four hybrid models such as public - private partnership, public - private community-based partnership, public with international cooperation and public - private partnership with international cooperation. Private and community models are unusual because both demand the support of the public sector to install higher power of RE. For instance, the community model is often applied when large RE projects are connected to the national grid (mainland), dependent on a wide range of institutional arrangements as well as funding programs, expert assistance and the entrepreneurial spirit of the communities [187]. Well-designed business models, which consider local conditions and limitations, favor greater RE penetration. These depend enormously on the political, financial, institutional, social, technological and environmental factors of each island. Fig. 2 shows the business models applied in the case studies compared with the RE share. Likewise, their definitions are explained below:

- In spite of the fact developed countries have applied a public business model, it is not the most common in small islands. This model is led by central and local governments and specialized bodies. The private sector participates in the implementation phase and the public sector is responsible for O\&M. This model requires solid regulations, a large investment capability and local capacities to hybridize thermal power plants.

- The hybrid models are the most common which distinguish islands belonging to developed countries from the least developed ones:

In developed regions, the hybrid model is characterized by the participation of public and private sectors and even of communities with an innovation culture. When research centers take part in business models, there is a constant innovation process to work on improving the stability of HRMGs. This business model is supported by robust regulatory frameworks and several and attractive mechanisms to promote, finance and make profitable investments in RE. As a rule, the private entity is also in charge of O\&M tasks directly or by a third party.

In the least developed islands, public with international cooperation, which is the most common hybrid model, discourages private companies from participating in RE deployment. Although the public sector creates horizontal and vertical partnerships to facilitate the management, it is hard to build solid alliances. The O\&M activity is the responsibility of local public companies which do not have enough local capacity to guarantee the sustainability of the projects. The lack of suitable policies and attractive incentives to fund projects is a considerable weakness. There is also a lack of trained human resources and a poor transfer of knowledge from implementing partners to local technicians. This model is economically unsustainable to fund large renewable power. Only when the electricity demand is lower, can small islands achieve high shares of RE with funding from the public sector and international cooperation, e.g., Tokelau ( $70 \%$ of RE share, $676 \mathrm{MWh} /$ year). Similarly, public-private with international cooperation, which has similar characteristics as the public with international cooperation model, has been an unsuccessful business model to establish a new market niche for RE technologies on these islands. Private participation is very limited due to conservative policies. Thus, concessions have no continuity over time.

Business models are also comparable in terms of the LCOE. On the island of Kodiak (100\% of RE share), where a public - private community-based partnership was applied to implement an HRMG, the generation costs are $11.6 \mathrm{USc} / \mathrm{kWh}$ with wind energy and $6.8 \mathrm{USc} / \mathrm{kWh}$ with hydroelectric energy, much more lower than the cost of diesel generation (28.9 USc/kWh - 92 USc/liter of diesel) [184]. In the Galapagos Islands, where a public with international cooperation was applied, the subsidized LCOE is $24.31 \mathrm{USc} / \mathrm{kWh}$ [188]. The RE share is on average $17 \%$ [189]. Unfortunately, there is no information on the real electricity generation cost. To reduce the economic impact on the ELECGALAPAGOS (local electricity company), the O\&M costs of the generation are settled in the National Interconnected System (SNI) [188]. Islands should audit their projects to foster decision making in policies and business models based on real market conditions.

For the deployment of renewable energy, a great variety of incentives have been used in developed islands, while these incentives have been insufficient in SIDS and the Galapagos Islands. This research identifies two possible options to accelerate $\mathrm{RE}$ introduction in these territories: competitive auctions and the RESCO model as regards the lower costs of renewable technologies. Well-designed and transparent auctions foster the expansion of wind and PV technologies in a costeffective manner $[190,191]$, decreasing the risk in those countries in which this is typically high [191]. This mechanism has replaced the application of feed-in tariffs in so many countries including the least developed [191,192]. This model has shown that it is possible to reactivate the electrical power sector, previously based on feed-in tariffs [190]. Investors get returns by selling electricity at established prices in PPAs, which come up from a competitive bidding process. Likewise, if auctions include upfront guarantees, this model can enable a robust financing process [191]. Moreover, the RESCO approach has been successfully implemented on the island of Graciosa through a shared savings scheme. In the least developed islands, the LCOE of new RE projects should be compared with the real generation prices of thermal power plants (without subsidies). Thereby, quantifying the government's profits will be possible. Graciosa is saving 2.4 million liters of diesel/year [180]. Nevertheless, tax incentives should be implemented to enhance RE opportunities.

For most islands belonging to developed countries, a liberalized market is sign of a secure investment while in others such as King Island, the institutional and technical capacities had made a successful deployment of REs possible when the power sector was a monopoly. The Necker case is very special as it is owned by a rich entrepreneur who is leading its energy diversification. In SIDS and the Galapagos Islands, the main constraints for RE deployment are weak institutional capacities and a lack of awareness of the efficient use of energy [35,40,92]. Moreover, these islands will not achieve their targets if these targets only

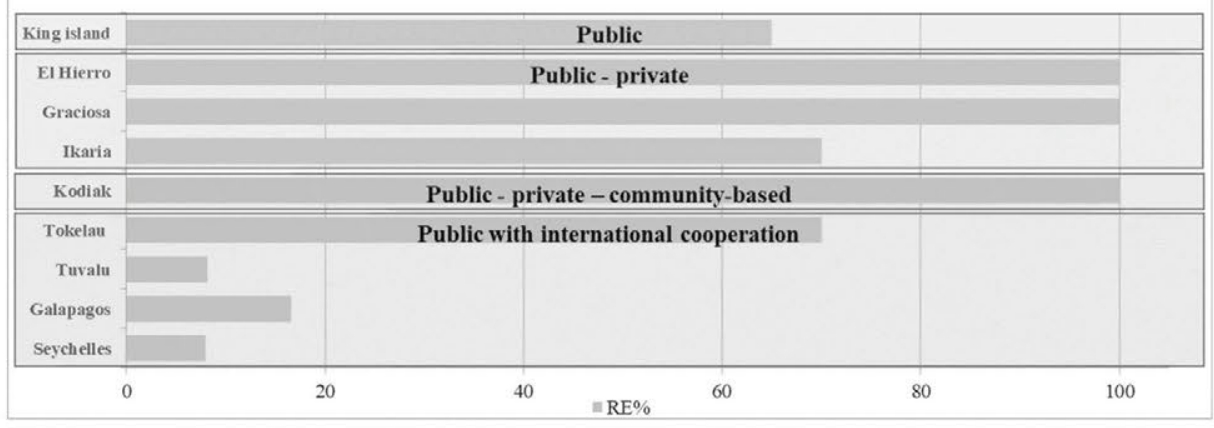

Fig. 2. Business models for HRMGs implementation vs RE share. 
depend on external financing. There, private participation is needed to support policies and regulations, transfer of knowledge and experiences and to solve funding issues. Furthermore, the design and implementation of projects could improve if the community takes part in understanding the contexts and decision making.

According to Amit and Zott [193], business models are designed based on four antecedents: goals, template, stakeholders and environmental constraints. As another study demonstrated [156], this research transfers this concept to the context of small islands, which determines that business models are influenced by:

- Goals: Increasing RE penetration, helping to mitigate climate change, reducing fossil fuel dependency, making electricity prices less costly and raising the rates of access to electricity - only in the Pacific and Indian islands-.

- Template: It is the design per se of a business model on every island.

- Stakeholders: Collaboration between public and private sectors, communities and international agencies and donors -only in the Pacific and Indian islands-. In a business model, all of the participants deserve the same importance regardless of their functions in the different stages of the project development. For instance, the participation of public administrations in business models is crucial to establish a regulatory framework and to promote, fund and assure the cost-effectiveness of REs.

- Environmental constraints (political, financial, institutional, social, technological and environmental): Constraints in the Pacific and Seychelles have not been considered in designing and implementing business models, e.g., one of the main barriers in SIDS is the institutional limitations because of the lack of qualified human resources in every professional role, especially in administrative and financial management tasks such as the preparation of proposals to facilitate access to funding [49,194]. Furthermore, SIDs are more vulnerable due to insufficient knowledge about energy and the scarce social commitment to the preservation of the environment of their population.

Business models are the guidelines to the implementation and success of HRMGs, whose design depends mainly on the island context and the interest, participation and commitment of multiple stakeholders. In SIDS and the Galapagos islands, financial aid has been crucial in implementing business models and installing renewable power. However, energy transition demands more than pure financial assistance. This should be more effective in terms of policies, capacities, and the exchange of experiences between developed and developing regions to attract private investment. These aspects need to be resolved for new RE projects, which have been an opportunity market for technology and companies from the donor's government. Energy transition demands a restructuring of the cooperation agenda, international financing and aid, which also implies the transparency of generation costs. Future research will be to assess how foreign aid should be redirected in line with supporting the energy transition of small islands, and the definition of suitable business models according to the context of the least developed islands.

\subsection{Overview of hybrid renewable mini-grids}

On islands in which there is no interconnection with the mainland, the implementation of RE requires an in-depth understanding of the context to guarantee energy security, access to electricity, a match between supply and demand, lower electricity prices and acquiring responsibilities for combating climate change. For this reason, this research has identified the main factors to take into account to plan and implement HRMGs on non-interconnected small islands. Table 6 shows these factors:

Considering the factors listed in the planning, design, and implementation of RE projects would be helpful in terms of economic efficiency and sustainability. These aspects deserve to be analyzed to identify the most suitable power system according to the context conditions and to solve the previous needs before or during the implementation of the project. For example, in protected areas due to their environmental value, the availability of the surface for the installation of PV plants, or wind generators, may be very limited, as in the case of the Galapagos Islands. Here, the National Park of the Galapagos Islands institution decides on the areas available for RE projects. As regards local capacities, on the island of Santa Cruz (the Galapagos Islands), after three years of operation of a PV system (1.5 MW), the O\&M staff has replaced several inverters (60/93) and modules (34/6007) without a previous analysis due to the lack of knowledge of PV systems. This cost half a million US Dollars [176]. After having interviewed part of the technical and administrative staff of ELECGALAPAGOS, the conclusion is that there are two major limitations to RE. The first, due to the lack of local engineers and trained technicians along with the insufficient planning and direction of training courses (financed by international aid). This highlights the importance of setting out appropriate training programs to implement, operate and maintain RE projects. The second, because of the logistics in islands: the transport, access and installation of heavy equipment to islands are limited. Both remoteness and orography affect investment costs. ELECGALAPAGOS also recognized that financial assistance is a key player in the deployment of RE, where private investment has absolutely no opportunity due to the current electricity legislation [151]. These reflect an opposite view of energy transition and the need to improve policies, capacities and to change the current implementation model of HRMGs towards another more sustainable outlook.

\section{Conclusions and policy implications}

This paper presents the state of the art of HRMGs implemented on non-interconnected small islands based on a review of 10 case studies. With this review, it has been possible to identify drivers and inhibitors of $\mathrm{RE}$ as well as business models to develop RE projects through an indepth understanding and analysis of the environment of small islands. Thereby, this research offers a new definition of business models and

Table 6

Key factors for the implementation of hybrid renewable mini-grids.

\begin{tabular}{|c|c|}
\hline Key factors & Category \\
\hline $\begin{array}{l}\text { Level of dependency of thermal power generation } \\
\text { Real cost of electricity generation (without subsidies) } \\
\text { Available land for use }\end{array}$ & $\begin{array}{l}\text { Size, remoteness and } \\
\text { insularity }\end{array}$ \\
\hline $\begin{array}{l}\text { Definition of the area available to install RE projects' } \\
\text { Protection of biodiversity } \\
\text { Obtaining environmental licenses } \\
\text { Prevention of oil spills } \\
\text { Mitigation of climate change } \\
\text { Reduction in the effects of natural disasters } \\
\text { Reduction in GHG emissions }\end{array}$ & Environmental \\
\hline $\begin{array}{l}\text { Available policies for promoting and funding RE, EE and } \\
\text { access to electricity } \\
\text { Available incentives for RE, EE and access to electricity } \\
\text { Local expertise in } \mathrm{RE} \\
\text { Existing stakeholders } \\
\text { Possibilities for private participation } \\
\text { Availability of financial assistance } \\
\text { Definition of business models }\end{array}$ & $\begin{array}{l}\text { Political, institutional, } \\
\text { financial }\end{array}$ \\
\hline $\begin{array}{l}\text { Non-interconnected power systems/Possibilities for } \\
\text { interconnection } \\
\text { Installed thermal power capacity } \\
\text { Stability of power systems } \\
\text { Renewable energy potential } \\
\text { Additional cost due to orography }\end{array}$ & Technical \\
\hline $\begin{array}{l}\text { Rates of electricity access } \\
\text { Main economic activities } \\
\text { Growth rate of population } \\
\text { Growth rate of electricity demand }\end{array}$ & Socio-economic \\
\hline
\end{tabular}


lists the key factors for the implementation of HRMGs to support planning and decision making. The results foster changing current paradigms of intervention and look for other ways of achieving RE targets. Energy planning should be oriented to take care of natural and ecological conditions in these vulnerable contexts.

Based on an analysis of the configuration of HRMGs, it is demonstrated that wind, PV, electromechanical storage and reliable control systems have a promising future on non-interconnected islands. RE technology implemented depends mainly on local conditions in terms of geography, resources, funding, research capacity and political willingness. Moreover, technological innovation helps islands to overcome the barriers related to their natural constraints. In these islands, the size of HRMGs varies from 1 to $90 \mathrm{MW}$, and wind and PV capacity have more presence on the Atlantic and the Pacific islands, respectively.

HRMGs are the most cost-effective and viable solution for noninterconnected small islands with the current prices of RE technologies. Public policies are crucial in the definition of business models to hybridize diesel generation plants. Similarly, suitable business models support the successful achievement of RE goals on small islands and, above all, the achievement of lower electricity prices, reliable electricity service, social-economic improvements and environmental benefits.

Islands belonging to developed countries have achieved high shares of RE thanks to the investment capacity of public and private sectors, local human resources, social awareness, a robust regulatory framework, attractive incentives for business, the introduction of different RE technologies and reliable control and storage systems. In SIDS and the Galapagos islands, the legal framework should guarantee a secure investment to solve the lack of local capacities and funding. In these territories, policies should not continue to be conservative and contradictory with the 2030 Agenda. Moreover, RE targets should be defined in a realistic way. The private sector has to be part of the introduction of RE. Thus, the public-private partnership would be the most suitable business model for those islands. Foreign aid should focus on establishing effective policies, awareness campaigns to involve society, and training programs via cooperation strategies with developed islands. This transfer of knowledge and experience may be more satisfactory due to their similar limitations. Finally, the RESCO business model or auctions with tax reductions could be considered the most attractive mechanisms to fund large-scale projects in the least developed islands.

\section{Acknowledgements}

The authors would like to thank the Universidad Politécnica de Madrid for the funds of the 17th Funding Call for University Cooperation to Development [grant number COOP-XVII-17] that made this research possible. The authors would also like to thank the Ecuadorian Ministry of Electricity and Renewable Energy, the Ecuadorian Electricity Company ELECGALAPAGOS and the Reiner Lemoine Institut for the provided information.

\section{References}

[1] Bazilian M, Nakhooda S, Van de Graaf T. Energy governance and poverty. Energy Res Soc Sci 2014;1:217-25.

[2] González-Eguino M. Energy poverty: an overview. Renew Sustain Energy Rev 2015:47:377-85.

[3] United Nations. The future we want. Brazil: Rio de Janerio; 2012.

[4] United Nations. United nations decade of sustainable energy for all. 2013.

[5] World Bank. Tracking SDG7: the energy progress report. 2018. Washington, DC.

[6] Yadoo A, Cruickshank H. The role for low carbon electrification technologies in poverty reduction and climate change strategies: a focus on renewable energy mini-grids with case studies in Nepal, Peru and Kenya. Energy Policy 2012;42: 591-602.

[7] Kempener R, Lavagne d'Origue O, Saygin D, Skeer J, Vinci S, Gielen D. Off-grid renewable energy systems: status and methodological issues. Abu Dhabi; 2015.

[8] Katsaprakakis DA. Hybrid power plants in non-interconnected insular systems. Appl Energy 2016;164:268-83.

[9] Sustainable Energy for All. High impact opportunity: clean energy mini-grids. 2014.
[10] Yan J, Zhai Y, Wijayatunga P, Mohamed AM, Campana PE. Renewable energy integration with mini/micro-grids. Appl Fnergy 2017;201:241-4.

[11] International Renewable Energy Agency. Accelerating off-grid renewable energy: key findings and recommendations from IOREC 2016. 2017. Abu Dhabi.

[12] International Renewable Energy Agency. Policies and regulations for renewable mini-grids. 2018. Abu Dhabi.

[13] International Renewable Energy Agency. Off-grid renewable energy solutions. 2018. Abu Dhabi.

[14] International Energy Agency. Energy access outlook 2017: from poverty to prosperity. 2017.

[15] Wiemann M, Rolland S, Glania G, Hybrid mini-grids for rural electrification: lessons learned. Brussels, Belgium: Alliance for Rural Electrification (ARE). United States Agency for International Development (USAID); 2014.

[16] Frankfurt School - UNEP Collaborating Centre for Climate and Sustainable Energy Finance. Renewable energy in hybrid mini-grids and isolated grids: economic benefits and business cases. Frankfurt, Germany: International Energy Agency; 2015.

[17] Blechinger P, Cader C, Bertheau P, Huyskens H, Seguin R, Breyer C. Global analysis of the techno-economic potential of renewable energy hybrid systems on small islands. Energy Policy 2016;98:674-87.

[18] Dornan M. Access to electricity in small island developing states of the pacific: issues and challenges. Renew Sustain Energy Rev 2014;31:726-35.

[19] Safdar T, Business models for mini-grids. Cambridge: Smart villages, Cambridge Malaysian Education and Development Trust (CMEDT), Malaysian Commonwealth Studies Centre (MCSC). Templeton World Charity Foundation (TWCF); 2017. Technical report 9.

[20] United Nations. The Millennium development goals report 2015. 2015. New York.

[21] Mendoza-Vizcaino J, Sumper A, Sudria-Andreu A, Ramirez JM. Renewable technologies for generation systems in islands and their application to Cozumel Island, Mexico. Renew Sustain Energy Rev 2016;64:348-61.

[22] Kuang Y, Zhang Y, Zhou B, Li C, Cao Y, Li L, et al. A review of renewable energy utilization in islands. Renew Sustain Energy Rev 2016;59:504-13.

[23] International Renewable Energy Agency. A path to prosperity: renewable energy for islands. 2016. Abu Dhabi.

[24] Bénard-Sora F, Praene JP. Territorial analysis of energy consumption of a small remote island: proposal for classification and highlighting consumption profiles. Renew Sustain Energy Rev 2016;59:636 48.

[25] Praene JP, Radanielina MH, Rakotoson VR, Andriamamonjy AL, Sinama F, Morau D, et al. Electricity generation from renewables in Madagascar: opportunities and projections. Renew Sustain Energy Rev 2017;76:1066-79.

[26] Howe E, Berlin H, Blechinger P, Cader C, Breyer C. Analyzing drivers and barriers for renewable energy integration to small islands power generation - tapping a huge market potential for mini-grids. In: Proceedings of the 2nd international conference on micro perspectives for decentralized energy supply. Berlin, Germany; 2013.

[27] Baldacchino G. Introducing a world of islands. In: Baldacchino G, editor. A world islands, Canada. Island Studies Press; 2007. p. 1-29.

[28] International Renewable Energy Agency. IRENA policy brief: policy challenges for renewable energy deployment in Pacific Island Countries and territories. Abu Dhabi; 2012.

[29] Department of Economic and Social Affairs. Trends in sustainable development small island developing states (SIDS). New York: United Nations; 2010.

[30] Mishra V, Smyth R, Sharma S. The energy-GDP nexus: evidence from a panel of Pacific Island countries. Resour Energy Econ 2009;31:210-20.

[31] Keeley AR. Renewable energy in Pacific Small Island Developing States: the role of international aid and the enabling environment from donor's perspectives. J Clean Prod 2017;146:29-36.

[32] Duić N, da Graça Carvalho M. Increasing renewable energy sources in island energy supply: case study Porto Santo. Renew Sustain Energy Rev 2004;8: 383-99.

[33] Campell A. Effects of oil price and global demand shocks on Small Island Developing States. Centre for Applied Macroeconomic Analysis, Crawford School of Public Policy, Australian National University; 2016.

[34] Briguglio L. Small island developing states and their economic vulnerabilities. World Dev 1995;23:1615-32.

[35] Lucas H, Fifita S, Talab I, Marschel C, Cabeza LF. Critical challenges and capacity building needs for renewable energy deployment in Pacific Small Island Developing States (Pacific SIDS). Renew Energy 2017;107:42-52.

[36] Cross S, Padfield D, Ant-Wuorinen R, King P, Syri S. Benchmarking island power systems: results, challenges, and solutions for long term sustainability. Renew Sustain Energy Rev 2017;80:1269-91.

[37] International Renewable Energy Agency. IOREC 2012 international off-grid renewable energy conference: key findings and recommendations. 2012. Abu Dhabi.

[38] Riva Sanseverino E, Riva Sanseverino R, Favuzza S, Vaccaro V. Near zero energy islands in the Mediterranean: supporting policies and local obstacles. Energy Policy 2014;66:592-602

[39] Selosse S, Garabedian S, Ricci O, Maïzi N. The renewable energy revolution of Reunion island. Renew Sustain Energy Rev 2018;89:99-105.

[40] Weir T. Renewable energy in the Pacific Islands: its role and status. Renew Sustain Energy Rev 2018:94:762-71.

[41] Richter M. Utilities' business models for renewable energy: a review. Renew Sustain Energy Rev 2012;16:2483-93. 
[42] Engelken M, Römer B, Drescher M, Welpe IM, Picot A. Comparing drivers, barriers, and opportunities of business models for renewable energies: a review. Renew Sustain Energy Rev 2016;60:795-809.

[43] World Bank. REToolkit: a resource for renewable energy development. 2008.

[44] Franz M, Peterschmidt N, Rohrer M, Kondev B. Mini-grid policy toolkit: policy and business frameworks for successful minigrid roll-outs. Eschborn, Germany: European Union Energy Initiative Partnership Dialogue Facility (EUEI PDF); 2014.

[45] Moner-Girona M, Solano-Peralta M, Lazopoulou M, Ackom EK, Vallve X, Szabó S Electrification of Sub-Saharan Africa through PV/hybrid mini-grids: reducing the gap between current business models and on site experience. Renew Sustain Energy Rev 2018;91:1148-61.

[46] Blechinger P, Seguin R, Cader C, Bertheau P, Breyer C. Assessment of the global potential for renewable energy storage systems on small islands. In: Proceedings of the 8th International Renewable Energy Storage Conference and Exhibition Energy Procedia; 2014. p. 294-300.

[47] Reiner Lemoine Institut. List of small islands. 2016

[48] International Renewable Energy Agency. Renewable energy opportunities and challenges in the pacific islands region: Tokelau. 2013. Abu Dhabi.

[49] International Renewable Energy Agency. Renewable energy opportunities and challenges in the pacific islands region: Tuvalu. 2013. Abu Dhabi.

[50] Government Council for the Galapagos Special Regime. Galapagos Plan 2015 2020. Plan for sustainable development and territorial ordering for the Galapagos special regime. Galapagos: Puerto Ayora; 2015.

[51] Bunker K, Doig S, Hawley K, Morris J. Renewable microgrids: profiles from islands and remote communities across the globe. Boulmer: Rocky Mountain Institute (RMI); 2015.

[52] National Bureau of Statistics. Seychelles in figures. Mahé, Seychelles: National Bureau of Statistics; 2016.

[53] Seychelles Energy Commission. Integrated energy study for Seychelles for 2015 . 2035: Part 1 \& 2. Victoria: Republic of Seychelles; 2015.

[54] Mandelli S, Barbieri J, Mereu R, Colombo E. Off-grid systems for rural electrification in developing countries: definitions, classification and a comprehensive literature review. Renew Sustain Energy Rev 2016;58:1621-46.

[55] Mohammed YS, Mustafa MW, Bashir N. Hybrid renewable energy systems for off grid electric power: review of substantial issues. Renew Sustain Energy Rev 2014; 35:527-39.

[56] Shivarama Krishna K, Sathish Kumar K. A review on hybrid renewable energy systems. Renew Sustain Energy Rev 2015;52:907-16.

[57] Neves D, Silva CA, Connors S. Design and implementation of hybrid renewable energy systems on micro communities: a review on case studies. Renew Sustain Energy Rev 2014;31:935-46.

[58] Ton DT, Smith MA. The U.S. Department of energy's microgrid initiative. Flectr J 2012;25:84-94.

[59] Hirsch A, Parag Y, Guerrero J. Microgrids: a review of technologies, key drivers, and outstanding issues. Renew Sustain Energy Rev 2018;90:402-11.

[60] Chauhan A, Saini RP. A review on Integrated Renewable Energy System based power generation for stand-alone applications: configurations, storage options, sizing methodologies and control. Renew Sustain Energy Rev 2014;38:99-120.

[61] Bhattacharyya SC, Palit D. Mini-grid based off-grid electrification to enhance electricity access in developing countries: what policies may be required? Energy Policy 2016;94:166-78.

[62] Morales J, The success keys of the renewable energies investment. The transition from an energy intensive economic model to a sustainable economic model. Madrid, Spain: Institute of Latin American Studies, University of Alcala; 2012

[63] Hazelton J, Bruce A, MacGill I. A review of the potential benefits and risks of photovoltaic hybrid mini-grid systems. Renew Energy 2014;67:222 9.

[64] Palaco I, Park MJ, Kim SK, Rho JJ. Public -private partnerships for e-government in developing countries: an early stage assessment framework. Eval Program Plann 2019;72:205-18.

[65] Williams NJ, Jaramillo P, Taneja J, Ustun TS. Enabling private sector investment in microgrid-based rural electrification in developing countries: a review. Renew Sustain Energy Rev 2015;52:1268-81.

[66] Pätäri S, Sinkkonen K. Energy service companies and energy performance contracting: is there a need to renew the business model? Insights from a delphi study. J Clean Prod 2014;66:264-71.

[67] Okay N, Akman U. Analysis of ESCO activities using country indicators. Renew Sustain Energy Rev 2010;14:2760-71.

[68] Bertoldi P, Rezessy S, Vine E. Energy service companies in European countries: current status and a strategy to foster their development. Energy Policy 2006;34 181832.

[69] Fernandes P, Pinho P. The distinctive nature of spatial development on small islands. Prog Plan 2017;112:1-18.

[70] Mimura N, Nurse L, McLean R, Agard J, Briguglio L, Lefale P, et al. Small islands In: Parry M, Canziani O, Palutikof J, van der Linden P, Hanson C, editors. Climate change 2007: impacts, adaptation and vulnerability. Cambridge: Cambridge University Press; 2007. p. 687-716.

[71] Dornan M. Renewable energy development in Small Island Developing States of the Pacific. Resources 2015;4:490-506.

[72] Tafia T, Herbert W. Pacific regional energy assessment 2004: an assessment of the key energy issues, barriers to the development of renewable energy to mitigate climate change, and capacity development needs to removing the barriers: Tokelau National Report. Samoa: The Secretariat of the Pacific Regional Environment Programme; 2004.
[73] National Department of Economic Regulation. Analysis of the cost and tariff of the electricity sector. Quito, Ecuador: Agency for Regulation and Control of Electricity (ARCONEL); 2016.

[74] Bussiness Unit Termopichincha. Fuel prices of Galapagos. Quito, Ecuador. Electricity Corporation of Ecuador (CELEC- EP); 2016.

[75] Reform for the regulation of the prices of the hydrocarbon derivatives. Decree No October 15, 2015;799.

[76] Agency for Regulation and Control of Electricity, Rate schedule for electric companies. Period: January - December 2017. Ecuador: Quito; 2017.

[77] Groppi D, Astiaso Garcia D, Lo Basso G, Cumo F, De Santoli L. Analysing economic and environmental sustainability related to the use of battery and hydrogen energy storages for increasing the energy independence of small islands. Energy Convers Manag 2018;177:64 76.

[78] Gorona del Viento El Hierro. Hydroelectric power plant El Hierro. The project, http://www.goronadelviento.es/index.php?accion-articulosseccion\&IdSeccion 73; . [Accessed 2 January 2019].

[79] Massot A. The agriculture of the Azores islands. Brussels, Belgium: European Parliament; 2015.

[80] Dóniz-Páez J, Becerra-Ramírez R, González-Cárdenas E. Geomorphosites and geotourism in volcanic landscape: the example of La Corona del Lajial Cinder Cone (El Hierro, Canary Islands, Spain). Geoj Tour Geosites 2011;8:185-97.

[81] Galapagos National Park Directorate. The management plan for the protected areas of Galapagos for good living. Puerto Ayora, Galapagos, Ecuador: Galapagos National Park. Ministry of Environment; 2014.

[82] Vintimilla L. Wind farm san cristobal - Ecuador. Loja, Ecuador. Eólica San Cristobal S.A. EOLICSA; 2013.

[83] Pérez JC, González A, Díaz JP, Expósito FJ, Felipe J. Climate change impact on future photovoltaic resource potential in an orographically complex archipelago, the Canary Islands. Renew Energy 2019;133:749-59.

[84] Himes-Cornell A, Hoelting K, Maguire C, Munger-Little L, Lee J, Fisk J, et alCommunity profiles for North Pacific fisheries - Alaska. NOAA technical memorandum NMFS-AFSC-259. Springfield, US: U.S. Department of Commerce; 2013.

[85] Chapman JB, Elliott J, Doser DI, Pavlis TL. Slip on the Suckling Hills splay fault during the 1964 Alaska earthquake. Tectonophysics 2014;637:191-7.

[86] Lemke R. The Alaska earthquake, march 27, 1964: effects on communities. Washington, DC: United States Department of the Interior; 1967.

[87] McLellan B, Zhang Q, Farzaneh H, Utama NA, Ishihara KN. Resilience, sustainability and risk management: a focus on energy. Challenges 2012;3: 15382.

[88] Chan D, Cameron M, Yoon Y. Key success factors for global application of micro energy grid model. Sustain Cities Soc 2017;28:209-24.

[89] Vivoda V. Japan's energy security predicament post-Fukushima. Energy Policy 2012:46:135-43.

[90] Suberu MY, Mustafa MW, Bashir N, Muhamad NA, Mokhtar AS. Power sector renewable energy integration for expanding access to electricity in sub-Saharan Africa. Renew Sustain Energy Rev 2013;25:630-42.

[91] Müller-Steinhagen H, Nitsch J. The contribution of renewable energies to a sustainable energy economy. Process Saf Environ Prot 2005;83:285-97.

[92] Surroop D, Raghoo P. Renewable energy to improve energy situation in African island states. Renew Sustain Energy Rev 2018;88:176-83.

[93] Raghoo P, Surroop D, Wolf F, Leal Filho W, Jeetah P, Delakowitz B. Dimensions of energy security in Small Island Developing States. Util Policy 2018;53:94-101.

[94] Martín Mederos AC, Medina Padrón JF, Feijóo Lorenzo AE. An offshore wind atlas for the Canary Islands. Renew Sustain Energy Rev 2011;15:612-20.

[95] Government of Tokelau. Solar Project. The worl's first truly renewable energy nation. http://www.tokelau.org.nz/Solar+Project.html. [Accessed 8 January 2019].

[96] Cevallos-Sierra J, Ramos-Martin J. Spatial assessment of the potential of renewable energy: the case of Ecuador. Renew Sustain Energy Rev 2018;81: $1154-65$.

[97] Kotroni V, Lagouvardos K, Lykoudis S. High-resolution model-based wind atlas for Greece. Renew Sustain Energy Rev 2014;30:479-89.

[98] Kaldellis JK, Zafirakis D. Present situation and future prospects of electricity generation in Aegean Archipelago islands. Energy Policy 2007;35:4623-39.

[99] Chadee XT, Clarke RM. Large-scale wind energy potential of the Caribbean region using near-surface reanalysis data. Renew Sustain Energy Rev 2014;30:45-58.

[100] Brown T, Ackermann T, Martensen N. Solar power integration on the Seychelles Islands. Field Actions Sci Rep 2016;(15):46-53.

[101] Liu J, Mei C, Wang H, Shao W, Xiang C. Mutual adaptability of renewable energy and water-supply systems in islands. Energy Procedia 2017;105:799 804.

[102] Meschede H, Holzapfel P, Kadelbach F, Hesselbach J. Classification of global island regarding the opportunity of using RES. Appl Energy 2016;175:251-8.

[103] Michalena E, Hills JM. Paths of renewable energy development in small island developing states of the South Pacific. Renew Sustain Energy Rev 2018;82: $343-52$.

[104] Azhar M, Zahir M, Zaman K, Arif M. Global estimates of energy-growth nexus: application of seemingly unrelated regressions. Renew Sustain Energy Rev 2014; 29:63-71.

[105] Menegaki AN. On energy consumption and GDP studies; A meta-analysis of the last two decades. Renew Sustain Energy Rev 2014;29:31-6.

[106] Younicos AG. Kodiak island battery park. 2017.

[107] McDowell Group.. The economic value of Alaska's seafood industry. Alaska See Food Marketing Intitute; 2017.

[108] Katircioglu ST. International tourism, energy consumption, and environmental pollution: the case of Turkey. Renew Sustain Energy Rev 2014;36:180-7. 
[109] Kurniawan F, Adrianto L, Bengen DG, Prasetyo LB. Vulnerability assessment of small islands to tourism: the case of the Marine Tourism Park of the Gili Matra Islands, Indonesia. Glob Ecol Conserv 2016;6:308-26.

[110] Gils HC, Simon S. Carbon neutral archipelago - 100\% renewable energy supply for the Canary Islands. Appl Energy 2017;188:342-55.

[111] International Renewable Energy Agency. Renewable energy countries profiles Pacific. Abu Dhabi; 2012

[112] United Nations. British Virgin Islands. 2015.

[113] Chatziargyriou N, Margaris I, Dimeas A. Renewable energy developments in Greek Islands. Athens, Greece: Friedrich Ebert Stiftung; 2016.

[114] BusinessSense King Island context analysis. King island. King Island Council; 2015.

[115] Colvin R, Witt B, Lacey J. How win became a four-letter word: lessons for community engagement from a wind energy conflict in King Island, Australia. Energy Policy 2016;98:483-94.

[116] Dorotić H, Doračić B, Dobravec V, Pukšec T, Krajačić G, Duić N. Integration of transport and energy sectors in island communities with $100 \%$ intermittent renewable energy sources. Renew Sustain Energy Rev 2019;99:109-24.

[117] International Renewable Energy Agency. National energy roadmaps for islands. 2016. Abu Dhabi.

[118] Cabrera P, Lund H, Carta JA. Smart renewable energy penetration strategies on islands: the case of Gran Canaria. Energy 2018;162:421-43.

[119] Official Gazette of Canary Islands. No. 107. July 26, 2002

[120] Government of Azores. Energy policy in the Azores promotes renewable energies. http://azores.gov.pt/Portal/en/entidades/sreat-dre/noticias/Energy+policy+in + the + Azores + promotes + renewable+energies.htm?mode=category. [Accessed 2 March 2019].

[121] Ministry of Foreign Affairs and Trade. Tokelau renewable energy project. New Zealand: Case study; 2013.

[122] Ministry of Electricity and Renewable Energy. Solar farm San Cristobal. Ecuador: Quito; 2016.

[123] Goman C. Case study: Necker Island, British Virgin Islands - among the most energy efficient islands in the world. http://microgridknowledge.com/case-st udy-necker-island-british-virgin-islands-among-the-most-energy-efficient-islands -in-the-world/. [Accessed 2 March 2019].

[124] Hamilton J, Negnevitsky M, Wang X, Lyden S. High penetration renewable generation within Australian isolated and remote power systems. Energy 2019; 168:684 92 .

[125] Hafeznia H, Aslani A, Anwar S, Yousefjamali M. Analysis of the effectiveness of national renewable energy policies: a case of photovoltaic policies. Renew Sustain Energy Rev 2017;79:669-80.

[126] United Nations Development Programme. Green energy for Galapagos, inexhaustible, clean and safe. Ecuador: Quito; 2016.

[127] International Renewable Energy Agency. Pacific lighthouses - renewable energy roadmapping for islands. 2013. Abu Dhabi.

[128] Ministry of Electricity and Renewable Energy. Electricity access rate. 2016.

[129] Tully S. The human right to access clean energy. Flectr J 2006;19:30-49.

[130] Demski C, Thomas G, Becker S, Evensen D, Pidgeon N. Acceptance of energy transitions and policies: public conceptualisations of energy as a need and basic right in the United Kingdom. Energy Res Soc Sci 2019;48:33-45.

[131] Streimikiene D, Siksnelyte I. Sustainability assessment of electricity market models in selected developed world countries. Renew Sustain Energy Rev 2016; 57:72-82.

[132] Younicos AG. Microgrids: Graciosa. https://www.younicos.com/case-studies/ graciosa/. [Accessed 11 April 2017].

[133] Mediterranean Energy Regulators. Assessments of mechanisms to integrate RES in isolated electricity systems in MEDREG countries. 2013.

[134] Arctic Council. Pillar mountain. USA: Kodiak, AK; 2015. http://www.arctic cou ncil.org/index.php/en/our-work2/8 news and events/334 pillar-mountain $\mathrm{k}$ odiak-ak. [Accessed 19 April 2017].

[135] Kodiak Electric Association. Member handbook. 2017.

[136] Abbott M, Cohen B. Finding a way forward: policy reform of the Australian national electricity market. Electr J 2018;31:65-72.

[137] National Renewable Energy Laboratory. Energy snapshot. British Virgin Islands; 2015.

[138] Renewable energy regulations. Statutory Instrument No September 27, 2018;51.

[139] Fernández S. The green metamorphosis of El Hierro. La Vanguardia; 2013 Mar 24

[140] Gorona del Viento El Hierro. Sustainable mobility. http://www. goronadelviento. es/index.php?accion=articulo\&IdArticulo-200\&IdSeccion=89;. [Accessed 2 January 2019].

[141] Voight A. Graciosa project overview. In: Proceedings of IRENA conference: renewables and islands global summit, St Julian's, Malta: younicos AG; 2012.

[142] e8 General Secretariat. Decreasing reliance on fuel and enhancing renewable energy based electrification in the Small Island State of Tuvalu: the Tuvalu solar power project. 2009.

[143] Masdar UAE. Tuvalu and Kiribati inaugurate two clean energy plants in the Pacific Region. http://www.masdar.ae/en/media/detail/uae-tuvalu-and-kiribatiinaugurate-two-clean-energy-plants-in-the-pacific-r. [Accessed 12 February 2018].

[144] Government of Tuvalu. Intended nationally determined contributions: communicated to the UNFCCC on 27 November 2015. 2015.

[145] Electricity Company ELECGALAPAGOS. Projects. http://www.elecgalapagos. com.ec/proyectos. [Accessed 5 March 2019]

[146] Heinemann E. ENERGAL - renewable energies for Galapagos. Quito, Ecuador. German International Cooperation Agency (GIZ); 2014.
[147] Eurelectric Energy Wisdom Programme 2010-2011 Edition. Improving energy efficiency and reducing carbon emissions. 2011.

[148] The European Commission. Hybrid energy project of Ikaria: energy sustainable island for real life community. https://ses.jrc,ec.europa.eu/hybrid-energy-proj ect-ikariaenergy-sustainable-island-real-life-community. [Accessed 22 March 2019].

[149] Masdar Clean Energy. Masdar special projects: port victoria wind power project (Seychelles). http://www.masdar.ae/en/energy/detail/seychelles-wind-farm. [Accessed 22 March 2019].

[150] Constitutional mandate No. 15. July 23, 2008

[151] Ecuadorian Organic Law of Public Electricity Service, Official Register No. 418 (January 16, 2015)

[152] Weisser D. Power sector reform in small island developing states: what role for renewable energy technologies? Renew Sustain Energy Rev 2004;8:101-27.

[153] Niles K, Lloyd B. Small island developing states (SIDS) \& energy aid: impacts on the energy sector in the Caribbean and Pacific. Energy Sustain Dev 2013;17: $521-30$.

[154] Wolf F, Surroop D, Singh A, Leal W. Energy access and security strategies in small island developing states. Energy Policy 2016:98:663-73.

[155] Newbery D, Pollitt MG, Ritz RA, Strielkowski W. Market design for a highrenewables European electricity system. Renew Sustain Energy Rev 2018;91: 695-707.

[156] Ahlgren K, Lagerstedt J. Business model translation - the case of spreading a business model for solar energy. Renew Energy 2019;133:23-31.

[157] Pérez-Díaz JI, Chazarra M, García González J, Cavazzini G, Stoppato A. Trends and challenges in the operation of pumped storage hydropower plants. Renew Sustain Energy Rev 2015;44:767-84.

[158] Bhandari B, Lee KT, Lee GY, Cho YM, Ahn SH. Optimization of hybrid renewable energy power systems: a review. Int J Precis Eng Manuf - Green Technol 2015;2: 99-112.

[159] Gorona del Viento El Hierro. We reached 1,000 hours with $100 \%$ of renewable energies. http://www.goronadelviento.es/index.php?accion=articulo\&IdArtic ulo-204\&IdSeccion=89; [Accessed 2 January 2019].

[160] Sarasúa JI, Martínez-Lucas G, Lafoz M. Analysis of alternative frequency control schemes for increasing renewable energy penetration in El Hierro Island power system. Int J Electr Power Energy Syst 2019;113:807-23.

[161] Bueno C, Carta JA. Technical-economic analysis of wind-powered pumped hydrostorage systems. Part II: model application to the island of E1 Hierro. Sol Energy 2005;78:396-405.

[162] Gómez Gotor A, Del Río Gamero B, Prieto Prado I, Casańas A. The history of desalination in the Canary Islands. Desalination 2018;428:86-107.

[163] Schallenberg-Rodríguez J, Veza JM, Blanco-Marigorta A. Energy efficiency and desalination in the Canary Islands. Renew Sustain Energy Rev 2014;40:741-8.

[164] Quang N. Hydro resources of the Galapagos archipelago. United Nations Educational, Scientific and Cultural Organization; 1985.

[165] Zakeri B, Syri S. Electrical energy storage systems: a comparative life cycle cost analysis. Renew Sustain Energy Rev 2015;42:569-96.

[166] Kaldellis JK, Zafirakis D, Kavadias K. Techno-economic comparison of energy storage systems for island autonomous electrical networks. Renew Sustain Energy Rev 2009;13:378-92.

[167] Tazvinga H, Xia X, Zhang J. Minimum cost solution of photovoltaic-diesel-battery hybrid power systems for remote consumers. Sol Energy 2013;96:292-9.

[168] Agarwal N, Kumar A, Varun. Optimization of grid independent hybrid PV-dieselbattery system for power generation in remote villages of Uttar Pradesh, India. Energy Sustain Dev 2013;17:210-9.

[169] Meza CG, Zuluaga Rodríguez C, D'Aquino CA, Amado NB, Rodrigues A, Sauer IL. Toward a $100 \%$ renewable island: a case study of Ometepe's energy mix. Renew Energy 2019;132:628 48.

[170] Esan AB, Agbetuyi AF, Oghorada O, Ogbeide K, Awelewa AA, Afolabi AE. Reliability assessments of an islanded hybrid PV-diesel-battery system for a typical rural community in Nigeria. Heliyon 2019;5:e01632.

[171] Malheiro A, Castro PM, Lima RM, Estanqueiro A. Integrated sizing and scheduling of wind/PV/diesel/battery isolated systems. Renew Energy 2015;83:646-57.

[172] Bensch G, Peters J, Sievert M. The lighting transition in rural Africa - from kerosene to battery-powered LED and the emerging disposal problem. Energy Sustain Dev 2017;39:13-20.

[173] Dehghani-Sanij AR, Tharumalingam E, Dusseault MB, Fraser R. Study of energy storage systems and environmental challenges of batteries. Renew Sustain Energy Rev 2019;104:192-208.

[174] Charles RG, Davies ML, Douglas P, Hallin IL, Mabbett I. Sustainable energy storage for solar home systems in rural Sub-Saharan Africa - a comparative examination of lifecycle aspects of battery technologies for circular economy, with emphasis on the South African context. Energy 2019;166:1207-15.

[175] Renewable Energies for Galapagos Islands (ERGAL). Summary of renewable electricity generation projects. Santa Cruz - Baltra Islands. Ecuador; 2013.

[176] Eras-Almeida AA, Egido-Aguilera MA. Quality control applied to the photovoltaic systems of the Galapagos islands: the case of Baltra and Santa Cruz. In: Proceedings of the 3rd International Hybrid Power System Workshop. Tenerife, Spain; 2018.

[177] Electricity Company ELECGALAPAGOS. Provincial Electricity Review 2016.

[178] Inter-American Development Bank. Ministry of electricity and renewable energy. Ecuador: National Plan for Energy Efficiency. Quito; 2017.

[179] Barelli L, Bidini G, Bonucci F, Castellini L, Fratini A, Gallorini F, et al. Flywheel hybridization to improve battery life in energy storage systems coupled to RES plants. Energy 2019;173:937-50. 
[180] Stenzel P, Schreiber A, Marx J, Wulf C, Schreieder M, Stephan L. Renewable energies for Graciosa Island, Azores - life cycle assessment of electricity generation. Energy Procedia 2017;135:62-74.

[181] Hourçourigaray J, Wary D, Bitot S. Renewable energy in the pacific islands: an overview and exemplary projects. Agence Française de Développement; 2014.

[182] Electricity Company ELECGALAPAGOS. The current state of the thermal generation of the Galapagos Islands. 2017.

[183] Electricity Company ELECGALAPAGOS. Monthly report: peak power. 2017.

[184] Kodiak Electric Association. Statistics of generation. http://www.kodiakelectric. $\mathrm{com} /$ generation.html. [Accessed 15 March 2019].

[185] Papaefthymiou SV, Karamanou EG, Papathanassiou SA, Papadopoulos MP. A wind-hydro-pumped storage station leading to high RES penetration in the autonomous island system of Ikaria. IEEE Trans Sustain Energy 2010;1:163-72.

[186] Asmus P, Lawrence M. Emerging microgrid business models. Boulder, USA: Navigant Consulting; 2016.

[187] Sperling K. How does a pioneer community energy project succeed in practice? The case of the Sams $\varnothing$ Renewable Energy Island. Renew Sustain Energy Rev 2017; 71:884-97.
[188] Agency for Regulation and Control of Electricity (ARCONEL). Cost of electricity service - Galapagos. 2019.

[189] Electricity Company ELECGALAPAGOS. Provincial Electricity Review 2018.

[190] Washburn C, Pablo-Romero M. Measures to promote renewable energies for electricity generation in Latin American countries. Energy Policy 2019;128: $212-22$.

[191] Dobrotkova Z, Surana K, Audinet P. The price of solar energy: comparing competitive auctions for utility-scale solar PV in developing countries. Energy Policy 2018;118:133 48.

[192] Atalay Y, Kalfagianni A, Pattberg P. Renewable energy support mechanisms in the Gulf Cooperation Council states: analyzing the feasibility of feed in tariffs and auction mechanisms. Renew Sustain Energy Rev 2017;72:723-33.

[193] Amit R, Zott C. Crafting business architecture: the antecedents of business model design. Strateg Entrep J 2015;9:331-50.

[194] Asian Development Bank. Impact evaluation study of bank assistance for power sector in the Pacific developing member countries. 1998. 